\title{
NEW RECORDS OF HOVERFLIES (DIPTERA, SYRPHIDAE) FROM UKRAINE. V
}

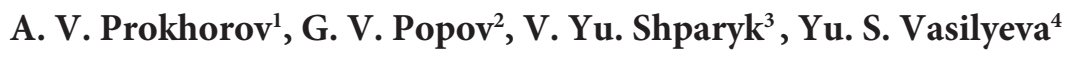 \\ ${ }^{1,2,4}$ Schmalhausen Institute of Zoology NAS of Ukraine \\ vul. B. Khmelnytskogo, 15, Kyiv, 01030 Ukraine \\ ${ }^{3}$ Vasyl Stefanyk Precarpathian National University, \\ vul. T. Shevchenko, 57, Ivano-Frankivsk, 76018 Ukraine \\ ${ }^{1}$ E-mail:al.val.prokhorov@gmail.com \\ ${ }^{2}$ E-mail: grigory.v.popov@gmail.com \\ ${ }^{3}$ E-mail: viktorshparyk@gmail.com
}

A. V. Prokhorov (https://orcid.org/0000-0002-3367-260X)

G. V. Popov (https://orcid.org/0000-0002-2519-1937)

New Records of Hoverflies (Diptera, Syrphidae) from Ukraine. V. Summary. Prokhorov, A. V., Popov, G. V., Shparyk, V. Yu., Vasilyeva, Yu. S. - Ten additional species of hoverflies of the subfamilies Eristalinae and Syrphinae are recorded from Ukraine for the first time: Cheilosia bergenstammi Becker, 1894, C. fraterna (Meigen, 1830), C. nebulosa Verrall, 1871, C. pascuorum Becker, 1894, C. uviformis Becker, 1894, Pelecocera scaevoides (Fallén, 1817), Dasysyrphus pauxillus (Williston, 1887), Epistrophe cryptica Doczkal and Schmid, 1994, Melangyna quadrimaculata (Verrall, 1873), and Xanthogramma dives (Rondani, 1857). Distributions of these species are summarized and species diagnoses are provided. An updated key to Cheilosia males of the group D sensu Becker (1894), which have tibiae with pale parts, is provided.

Key words: flower flies, Cheilosia, Dasysyrphus, Epistrophe, Melangyna, Pelecocera, Xanthogramma, new records, Ukraine.

\section{Introduction}

While compiling the checklist of Ukrainian syrphids several hoverfly species of the subfamilies Eristalinae and Syrphinae previously unknown from Ukraine were collected by the authors or were found in the collection of the Institute of Zoology, Kyiv.

Five species of the predominantly phytophagous genus Cheilosia Meigen, 1822, are recorded from Ukraine for the first time. Also one species of each of the following genera Pelecocera Meigen, 1822 (preimaginal stages undescribed, but possibly phytophagous (Kuznetsov, 1992; Speight, 2020)), and aphidophagous Dasysyrphus Enderlein, 1938, Epistrophe Walker, 1852, Melangyna Verrall, 1901, and Xanthogramma Schiner, 1860 (Rotheray, 1994; Speight, 2020) are recorded for the first time for Ukraine. 
The genera Cheilosia and Pelecocera belong to the tribe Rhingiini (Ståhls et al., 2004; Vujić et al., 2018). Cheilosia is a highly speciose genus with 446 species primarily distributed in the Holarctic Region (Vujić et al., 2018). After the Catalogue of Palaearctic Syrphidae (Peck, 1988), where Chamaesyrphus Mik, 1895 was accepted in a generic status, it was considered for many years to be a subgenus of Pelecocera followed by Thompson \& Rotheray (1998) and Ståhls et al. (2004). Recently, the supraspecific taxonomy of these taxa has been critically revised by Vujić et al. (2018), and, in particular, this study treated Chamaesyrphus as a subgenus of Pelecocera.

Within Syrphinae, the genera Dasysyrphus Enderlein, 1938, Epistrophe Walker, 1852, Melangyna Verrall, 1901 and Xanthogramma Schiner, 1860 belong to the tribe Syrphini sensu stricto (Mengual et al., 2008). The genera Dasysyrphus, Epistrophe and Melangyna were represented in Ukraine by seven, eight and five species, respectively (Lezhenina, 1993; Popov, 1994; Prokhorov et al., 2017, 2018 c). According to the current data, eight European Xanthogramma species are known (Nedeljković et al., 2018; Speight, 2020); four of them have been found in Ukraine (Lezhenina, 1993; Popov, 1994; Prokhorov et al., 2018 c; Lezhenina et al., in prep.). In this paper, we provide new records of the fifth species, X. dives (Rondani, 1857), from Ukraine. After Nedeljković et al. (2018), where the new species concepts were supported by morphological and molecular evidence, it turned out that at least in Polissia (Northern Ukraine) this species is the most common among species of Xanthogramma. Distributional ranges of Ukrainian Xanthogramma species emphasize the predominantly nemoral character of our fauna, while the other species of the genus are distributed in the Mediterranean region: X. aeginae Ricarte, Nedeljković \& Vujić, 2018 and X. pilosum Nedeljković, Ricarte \& Vujić, 2018 in Greece only, and X. marginale (Loew, 1854) from Morocco and Portugal to Italy (Nedeljković et al., 2018; Speight, 2020).

This article continues the series of papers reporting the first records of the hoverflies from Ukraine (Prokhorov \& Popov, 2017; Prokhorov et al., 2017, 2018 a-c, 2020).

\section{Material and methods}

All the specimens are deposited in the collection of the I. I. Schmalhausen Institute of Zoology, National Academy of Sciences of Ukraine, Kyiv (Ukraine).

We follow mainly the morphological terminology of Cumming \& Wood (2017), and partly of Speight (1987). Diagnoses are generally based on the keys by Bartsch et al. (2009 a, b), Van Veen (2010), Vujić et al. (2013) and Speight \& Sarthou (2017).

All photographs were taken using a Canon PowerShot A640 camera mounted on Carl Zeiss Stemi 2000 binocular microscope; all images were subsequently combined with Helicon Focus (version 6.0.18) and processed in Adobe Photoshop CS6 by A. V. Prokhorov.

\section{Subfamily Eristalinae}

\section{Tribe Rhingiini Subtribe Cheilosiina}

\section{Cheilosia (Cheilosia) bergenstammi Becker, 1894 (figs 1-8)}

Material examined.Ukraine. Volyn Region: Kholopychi env., 50.808819 N 24.749204 E, 16.07.2019, 1 ơ (V. Kavurka); Rivne Region: Bushcha env.: 50.295 N 26.284 E, Zbytynka River floodplain, 11.05.2018, 1 O'; Myzotskyi Kriazh, 50.30 N 26.30 E, deciduous forest, 17.05.2019, 1 ○’ (A. Prokhorov).

Distribution: Austria, Belarus, Belgium, Bosnia and Herzegovina, the Czech Republic, Denmark, France, Germany, Great Britain, Hungary, Ireland, Italy, Latvia, Liechtenstein, Luxembourg, Montenegro, the Netherlands, Norway, Poland, Romania, southern European Russia, Serbia, the Slovak Republic, Northern Spain, Sweden, Switzerland; Transcaucasia (the Republic of Georgia) (Bańkowska, 1963; Peck, 1988; Kuznetzov, 1993; Verlinden, 1991; Maibach et al., 1992; Dirickx, 1994; Belcari et al., 1995; Vujić, 1996; Holinka \& Mazánek, 1997; Wolff, 1998; Nielsen, 1999; Carrières, 2001a; Stubbs \& Falk, 2002; Stănescu \& Pârvu, 2005; Mielczarek, 2009-2020; Reemer et al., 2009; Tóth, 2011; Borodin \& Borodina, 2014; Ricarte \& Marcos-García, 2017; Barkalov \& Mutin, 2018; Speight et al., 2018; Mengual et al., 2020; Speight, 2020; Wakkie, 2020); Ukraine (first record).

Diagnosis. Cheilosia bergenstammi belongs to the species group D of Cheilosia (sensu Becker, 1894), which is characterized by the compound eye pilose (entirely or partly), lower part of face without pile, legs with yellow (at least tibiae yellow on both sides), posterior edge of scutellum with pile and setae. The male of C. bergenstammi is most similar to C. fraterna (Meigen, 1830) (figs 9-16), and somewhat similar to C. carbonaria Egger, 1860, 
C. cynocephala Loew, 1840, C. sootryeni Nielsen, 1970, and C. vernalis (Fallén, 1817) in having facial width (just below antennal sockets) not exceeding eye width at the same level, katepisternum with upper and lower patches of pile widely separated, at least tibiae with pale parts, hind femur ventrally with numerous thick setae, and hypopygium with pale pile. Cheilosia bergenstammi differs from the last four species by: compound eye with yellowish or light brown pile, at the lower part of eye without pile (figs 6-8) (in others, eye entirely covered in dark pile, except $C$. sootryeni with light brown pile and lower part of eye almost bare); fore and mid tarsi with tarsomeres $1-3$ yellow (figs 4,5 ), at most first tarsomere of
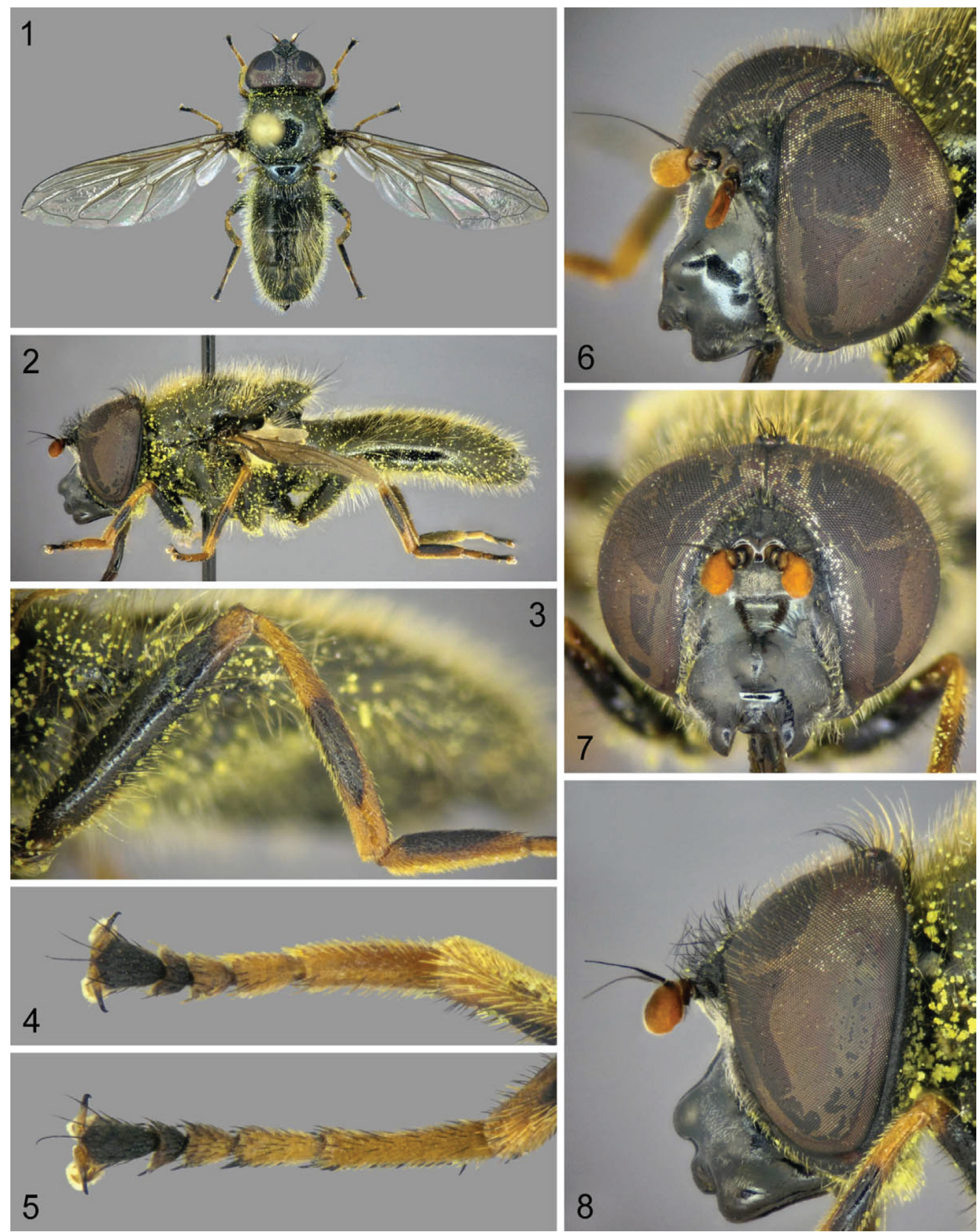

Figs 1-8. Cheilosia bergenstammi male: 1 - habitus, dorsal view; $2-$ habitus, lateral view; 3 - hind femur and tibia, lateral view; 4 - fore tarsus, dorsal view; 5 - mid tarsus, dorsal view; 6 - head, anterolateral view; 7 - head, frontal view; $8-$ head, lateral view. 
the fore tarsus may be darkened dorsally (in others, fore and mid tarsi entirely black; in C. vernalis, first tarsomere (rarely tarsomere 2 also) of mid leg may be yellow or brownish, sometimes only at the base); tergites 2 and 3 with only pale and mostly erect pile (in others, at least tergite 3 and usually tergite 2 with a central patch of black pile or seta-shaped macrotrichia, which are often adpressed or semi-adpressed).

Cheilosia bergenstammi also differs from C. carbonaria by: abdomen elongated-oval with almost parallel sides of tergite 3 (in C. carbonaria, abdomen elongated, expanding to posterior margin of tergite 3 , with the largest width in this place); wing hyaline with yellowish tint (fig. 1) (in C. carbonaria, wing distinctly darkened along the front edge and in the middle); hind tibia with distinct black ring occupying almost half of the tibia (fig. 3) (in C. carbonaria, hind tibia almost black with only brownish base).

Cheilosia bergenstammi also differs from C. cynocephala by: mesonotum black with bronze tinge (in C. cynocephala, mesonotum black with bluish tinge); tibiae yellow with black ring occupying not more than half of the tibia (fig. 2) (in C. cynocephala, tibiae with black ring occupying usually more than half of the tibia); mesopleura with pale pile (in C. cynocephala, mesopleura with pale and black pile mixed).

Cheilosia bergenstammi also differs from $C$. sootryeni by: tibiae with yellow apex occupying not less than $1 / 4$ of the tibia (fig. 2) (in C. sootryeni, tibiae with yellow apex occupying not more than 1/8-1/6 length of the tibia); mesopleura with pale pile (in C. sootryeni, mesopleura with pale and black pile mixed).

Cheilosia bergenstammi also differs from C. vernalis by: lower part of face more elongated, so that the facial tubercle usually extends beyond first flagellomere (basoflagellomere) (in C. vernalis, lower part of face less elongated, so that the facial tubercle doesn't extend beyond the first flagellomere). Unfortunately, C. vernalis is one of the most variable species of the genus, and listed characters may be completely different.

The Cheilosia bergenstammi male is also similar to the male of C. fraterna (figs 9-16), in addition to the above characters, in having compound eye with lower part bare, wing hyaline with yellowish tint, and tergites 2 and 3 with only pale pile. From $C$. fraterna it can be separated by: scutellum with pile and setae at least as long as scutellum (fig. 2) (in C. fraterna, scutellum with pile and setae half or slightly more than half as long as scutellum (fig. 10), scutellum often without setae); abdomen elongated-oval with almost parallel sides of tergite 3 (fig. 1) (in C. fraterna, abdomen wide oval, distinctly with largest width at the posterior edge of tergite 2 , as in fig. 9); fore and mid tarsi with tarsomeres 1-3 pale (figs 4,5 ), at most first tarsomere of the fore tarsus darkened dorsally (in C. fraterna, fore tarsus black dorsally (fig. 12) with at least tarsomeres $1+2$ pale laterally, mid tarsus (fig. 13) with first tarsomere usually pale and tarsomeres $2-5$ darkened dorsally); hind tibia (fig. 3 ) with distinct black ring occupying almost half of tibia (in C. fraterna, hind tibia with weak, incompletely developed dark ring (fig. 11), which may be reduced).

Genitalia of C. bergenstammi have been prepared and compared with figures in Stubbs \& Falk (2002: Plate H, fig. 1, a-c) and Barkalov (1993: figs 156-158).

\section{Cheilosia (Cheilosia) fraterna (Meigen, 1830) (figs 9-21)}

Material examined.Ukraine. Rivne Region: Bushcha env.: 50.29 N 26.28 E, Zbytynka River floodplain, 11.05.2018, 1 ○’, 1 ᄋ, 19.05.2019, 1 ○; 50.30 N 26.24 E, Zbytynka River floodplain forest, 12.05.2018, 2 ,

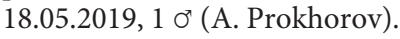

Distribution: Austria, Belarus, Belgium, Bosnia and Herzegovina, the Czech Republic, Denmark, Finland, France, Germany, Great Britain, Hungary, Ireland, Italy, Latvia, Liechtenstein, Lithuania, Luxembourg, the Netherlands, Norway, Poland, Portugal, Romania, European Russia, Serbia, the Slovak Republic, Slovenia, Spain, Sweden, Switzerland; Transcaucasia (the Republic of Georgia) (Bańkowska, 1963; Peck, 1988; Verlinden, 1991; Maibach et al., 1992; Kuznetzov, 1993; Dirickx, 1994; Belcari et al., 1995; Vujić, 1996; Ho- 
linka \& Mazánek, 1997; Wolff, 1998; Nielsen, 1999; Carrières, 2001 a; Stubbs \& Falk, 2002; Stănescu \& Pârvu, 2005; Pakalniškis et al., 2006; De Groot \& Govedič, 2008; Bartsch et al., 2009 b; Mielczarek, 2009-2020; Reemer et al., 2009; Tóth, 2011; Van Eck, 2011; Van Steenis et al., 2013; Borodin \& Borodina, 2014; Haarto \& Kerppola, 2014; Ricarte \& Marcos-García, 2017; Barkalov \& Mutin, 2018; Speight et al., 2018; Mengual et al., 2020; Speight, 2020; Wakkie, 2020); Ukraine (first record).

Diagnosis. Cheilosia fraterna is most similar to C. bergenstammi (see above). The male of C. fraterna (figs 9-16) is also similar to C. sootryeni in having lower part of com-
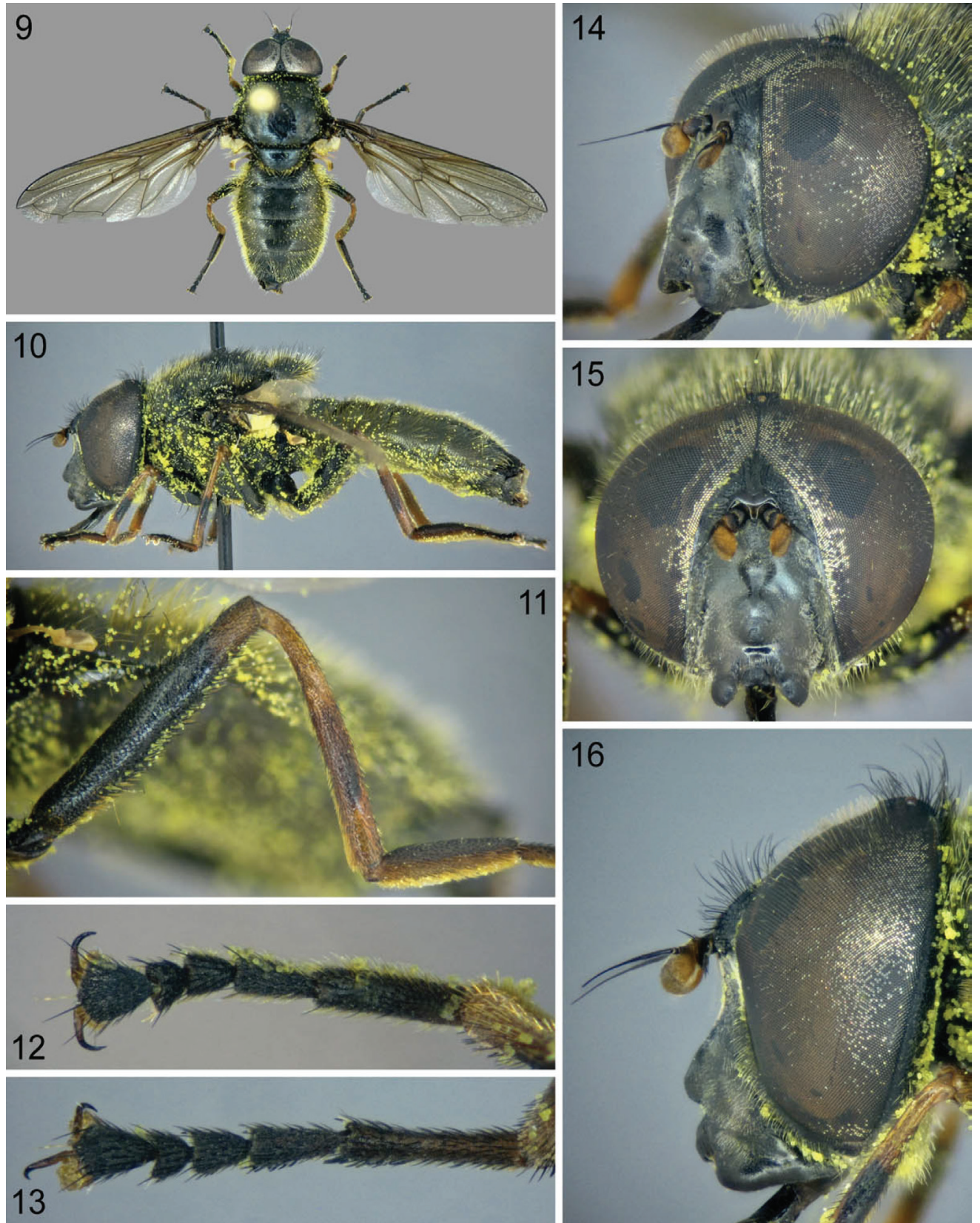

Figs 9-16. Cheilosia fraterna male: 9 - habitus, dorsal view; 10 - habitus, lateral view; 11 - hind femur and tibia, lateral view; 12 - fore tarsus, dorsal view; 13 - mid tarsus, dorsal view; 14 - head, anterolateral view; 15 - head, frontal view; 16 - head, lateral view. 

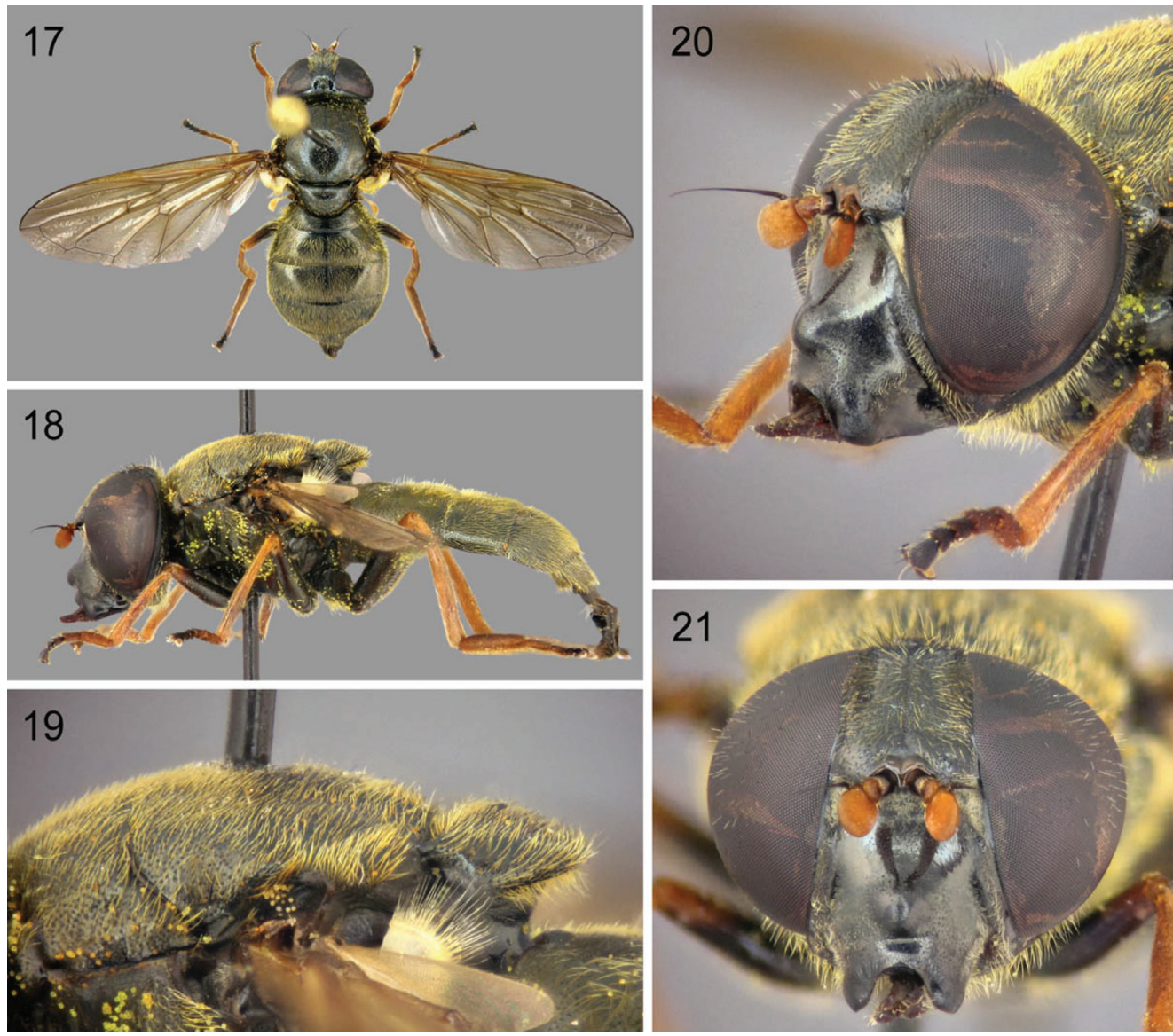

Figs 17-21. Cheilosia fraterna female: 17 - habitus, dorsal view; 18 - habitus, lateral view; 19 - mesonotum, lateral view; 20 - head, anterolateral view; 21 - head, frontal view.

pound eye bare (figs 14-16) (in C. sootryeni, lower part of compound eye may be bare or with a single pile); from $C$. sootryeni it can be distinguished by: tergites with mostly pale pile (in C. sootryeni, tergites 2 and 3 with black short macrotrichia posteromedially); tibiae with yellow apexes occupying almost 1/3-1/4 length of tibia (fig. 10), at that hind tibia may be entirely yellow (in C. sootryeni, tibiae with yellow apexes occupying not more than $1 / 8-1 / 6$ length of tibia); fore tarsus black dorsally (fig. 12) with at least tarsomeres $1+2$ pale laterally, mid tarsus (fig. 13) with first tarsomere usually pale and tarsomeres 2-5 darkened dorsally (in C. sootryeni, all tarsi black dorsally).

Genitalia of C. fraterna have been prepared and compared with figures in Stubbs \& Falk (2002: Plate I, fig. 1, a-d).

The female (figs 17-21) of C. fraterna is very similar to C. chloris (Meigen, 1822) and C. bracusi Vujić \& Claussen, 1994. From C. chloris it can be separated by: arista black at the base (fig. 20) (in C. chloris, arista yellow at the base); compound eye with the lower part (almost half of the eye) bare (figs 20-21) (in C. chloris, eye with the small lowest part bare or with single pile).

Cheilosia (Cheilosia) nebulosa Verrall, 1871 (figs 22-25)

= langhofferi Becker, 1894

Material examined.Ukraine. Zakarpattia: Kamianytsia env., 48.70 N 22.43 E, Uzh River valley (left bank), 6.05.2017, 1 o (G. Popov); Kyiv Region: Mygalky env., 50.655 N 29.495 E, Teteriv River floodplain, 17.04.2020, 1 ơ, 1 (A. Prokhorov). 
Distribution: Belarus, Belgium, Bosnia and Herzegovina, Bulgaria, Croatia, the Czech Republic, Denmark, Estonia, Finland, France, Germany, Great Britain, Hungary, Ireland, Italy, Latvia, Lithuania, Montenegro, Norway, Poland, Romania, Serbia, the Slovak Republic, Slovenia, Sweden, Switzerland; Russia (northern and central European part, Western and Central Siberia) (Bańkowska, 1963 (also as langhofferi); Peck, 1988; Verlinden, 1991; Maibach et al., 1992; Kuznetzov, 1993; Dirickx, 1994; Belcari et al., 1995; Vujić, 1996; Holinka \& Mazánek, 1997; Nielsen, 1999; Stubbs \& Falk, 2002; Stănescu \& Pârvu, 2005; Pakalniškis et al., 2006; Bartsch et al., 2009 b; Mielczarek, 2009-2020; Tóth, 2011, 2014 (also as langhofferi); Ball \& Morris, 2014; Borodin \& Borodina, 2014; Haarto \& Kerppola, 2014; Barkalov \& Mutin, 2018; Miličić et al., 2018; Speight et al., 2018; Speight, 2020; Wakkie, 2020); Ukraine (first record).

Diagnosis. Cheilosia nebulosa belongs to Cheilosia species group C (Claussen \& Speight, 1988; Bartsch et al., 2009 b). It has following characters: compound eye at least partly pilose, lower part of the face without pile, posterior edge of scutellum without setae. This species is similar to C. chrysocoma (Meigen, 1822) and C. subpictipennis Claussen, 1998 in having wing darkened in the middle, at least around crossvein r-m.

From C. chrysocoma, the female of C. nebulosa differs by: first flagellomere with rounded apex (fig. 25) (in C. chrysocoma, first flagellomere with angular apex, sometimes it may be poorly noticeable); face more or less parallel-sided (fig. 24) (in C. chrysocoma, face distinctly expands down); mesonotum with short yellowish pile (fig. 23) (in C. chrysocoma, mesonotum with long reddish pile); katepisternum with lower and upper parts of pile widely separated (in C. chrysocoma, katepisternum with lower and upper parts of pile more or less confluent); abdomen with not so dense, yellowish pile, shorter than thickness of the femur (figs 22, 23) (in C. chrysocoma, abdomen with dense, usually reddish pile, longer than thickness of the femur); (Bartsch et al., 2009 b, Van Veen, 2010).
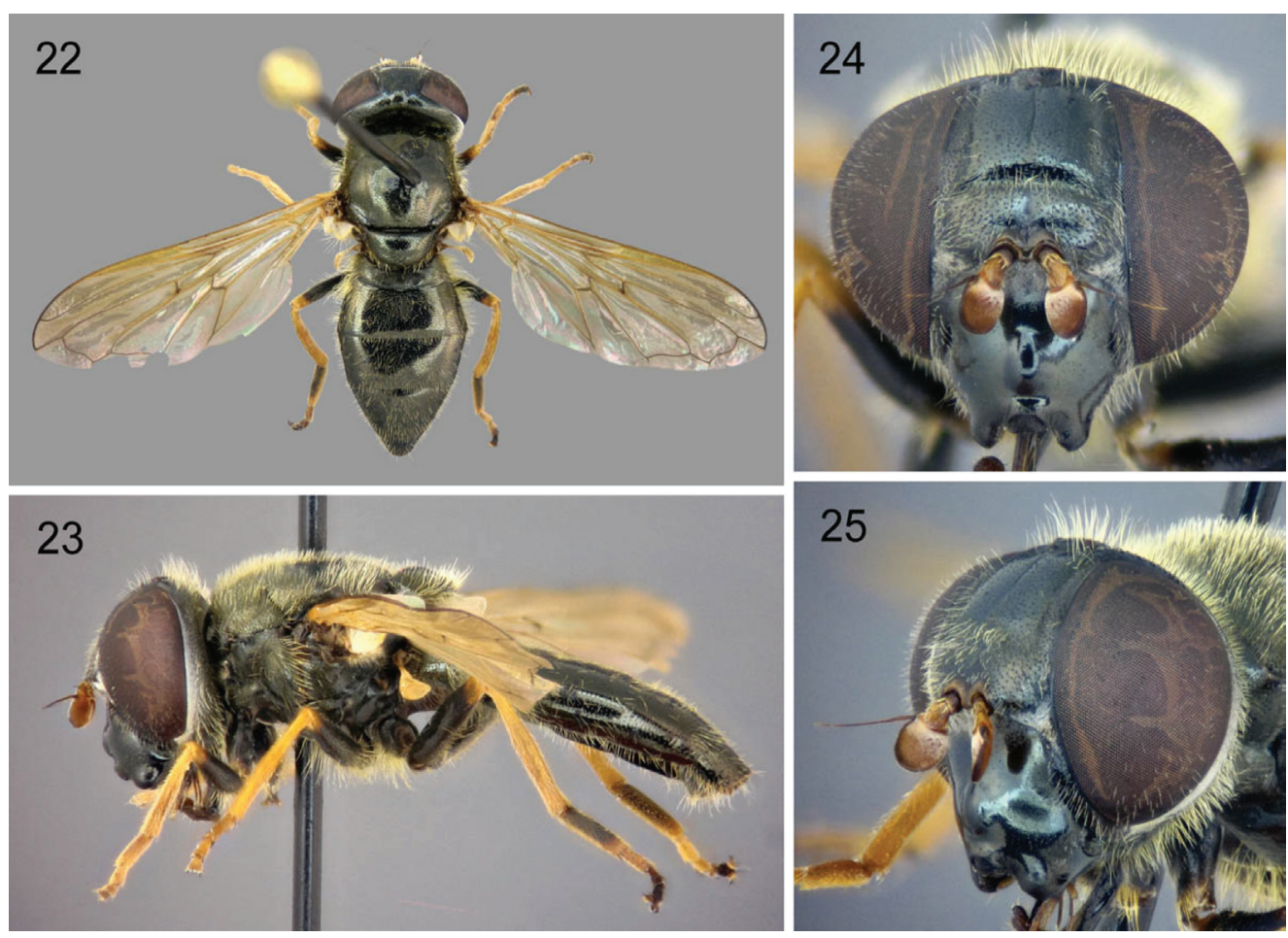

Figs 22-25. Cheilosia nebulosa female: 22 - habitus, dorsal view; 23 - habitus, lateral view; 24 - head, frontal view; 25 -head, anterolateral view. 
Cheilosia nebulosa can be separated from C. subpictipennis Claussen, 1998 by first flagellomere with dorsal margin and apex dark (fig. 25) (in C. subpictipennis, first flagellomere entirely pale) (Van Veen, 2010).

Specimens of this species with unmarked wing (as our specimen on fig. 22) have also appeared in literature under the name C. langhofferi Becker, 1894 (Speight, 2020). This taxon has been synonymized with C. nebulosa by Claussen \& Speight (1988).

Note. In Great Britain, this species is listed under the UK Biodiversity Action Plan and qualifies as Nationally Scarce (Ball \& Morris, 2014).

Cheilosia (Cheilosia) pascuorum Becker, 1894 (figs 26-29)

Material exa mined. Ukraine. Kyiv Region: Mali Dmytrovychi env., 50.22 N 30.52 E, ravine, 23.04.2018, 3 ơ; Mygalky env.: 50.66 N 29.50 E, mixed forest near Teteriv River floodplain, 28.04.2018, 1 ơ; 50.655 N 29.495 E, Teteriv River floodplain, 23.04-6.05.2020, 3 ơ, 2 ○ (A. Prokhorov).

Distribution: Austria, Bosnia and Herzegovina, Croatia, the Czech Republic, France, Germany, Greece, Montenegro, North Macedonia, Poland, Romania, central European Russia, Serbia, the Slovak Republic, Sweden, Switzerland (Bańkowska, 1963; Peck, 1988; Dirickx, 1994; Vujić, 1996; Holinka \& Mazánek, 1997; Wolff, 1998; Stănescu \& Pârvu, 2005; Mielczarek, 2009-2020; Vujić et al., 2013; Barkalov \& Mutin, 2018; Speight et al., 2018; Speight, 2020; Wakkie, 2020); Ukraine (first record).

Diagn osis. This species belongs to Cheilosia proxima group (Vujić et al., 2013) and is most similar to Cheilosia balkana Vujić, 1994 in having first flagellomere black to blackishbrown, margin of upper calypter with short pale pile, frons not swollen, abdomen (including pregenital segments) covered in pale macrotrichia (Vujić et al., 2001). The Cheilosia pascuorum male can be separated from the male of $C$. balkana by: tergite 3 dull medially (in C. balkana, tergite 3 shiny); vein $\mathrm{M}_{1}$ meeting vein $\mathrm{R}_{4+5}$ at right or obtuse angle (fig. 26) (in C. balkana, vein $\mathrm{M}_{1}$ meeting vein $\mathrm{R}_{4+5}$ at an acute angle); arista bare (fig. 29) (in C. balkana,
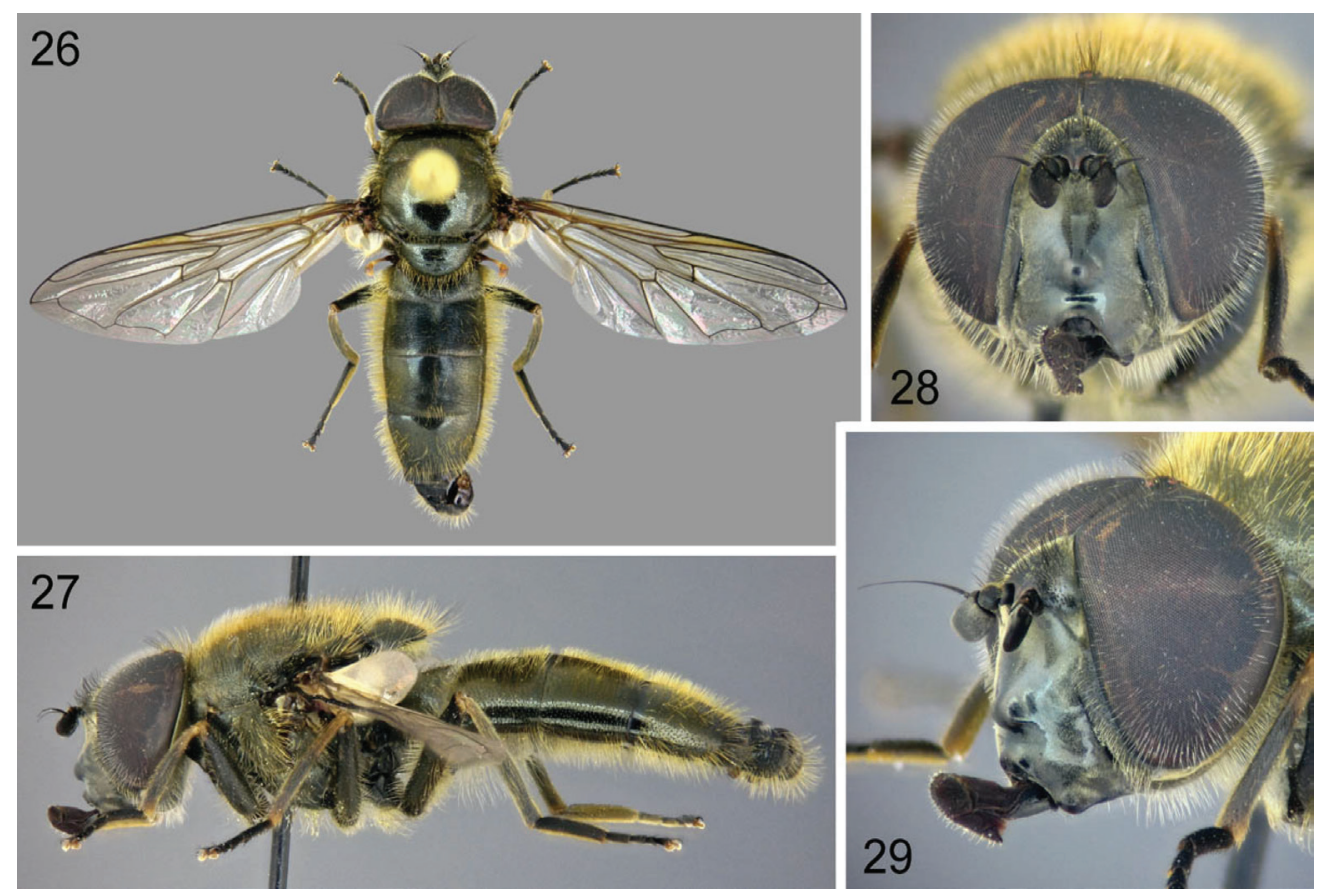

Figs 26-29. Cheilosia pascuorum male: 26 - habitus, dorsal view; 27 - habitus, lateral view; 28 - head, frontal view; 29 - head, anterolateral view. 
arista with short microtrichia); dorsal lobe of gonostylus very broad basally (in C. balkana, dorsal lobe of gonostylus basally narrowed) (Vujić et al., 2001). From the similar species C. proxima (Zetterstedt, 1843) and C. gigantea (Zetterstedt, 1838), C. pascuorum can be separated by: abdomen entirely with pale macrotrichia (figs 26,27) (in others, abdomen partly with black macrotrichia, at least pregenital segments with a few black macrotrichia). Additionally, from C. proxima it differs by its larger size, usually not smaller than $10 \mathrm{~mm}$ (C. proxima is smaller, usually 7-9 $\mathrm{mm}$ ). Genitalia of these species are different by the shape of the dorsal lobe of the gonostylus (Vujić et al., 2001).

The genitalia of C. pascuorum have been prepared and compared with figures in Vujić et al. (2001).

Note. This species is regarded as generally endangered in Europe (Vujić et al., 2001).

Cheilosia (Cheilosia) uviformis Becker, 1894 (figs 30-35)

Material examined.Ukraine. Kyiv Region: Kyiv, Muromets Is. on Dnipro River, 50.5058 N 30.5443 E, on flowers of Acer platanoides, 6.04.2017, 1 ơ, 18.04.2018, 1 Ơ' (A. Prokhorov).
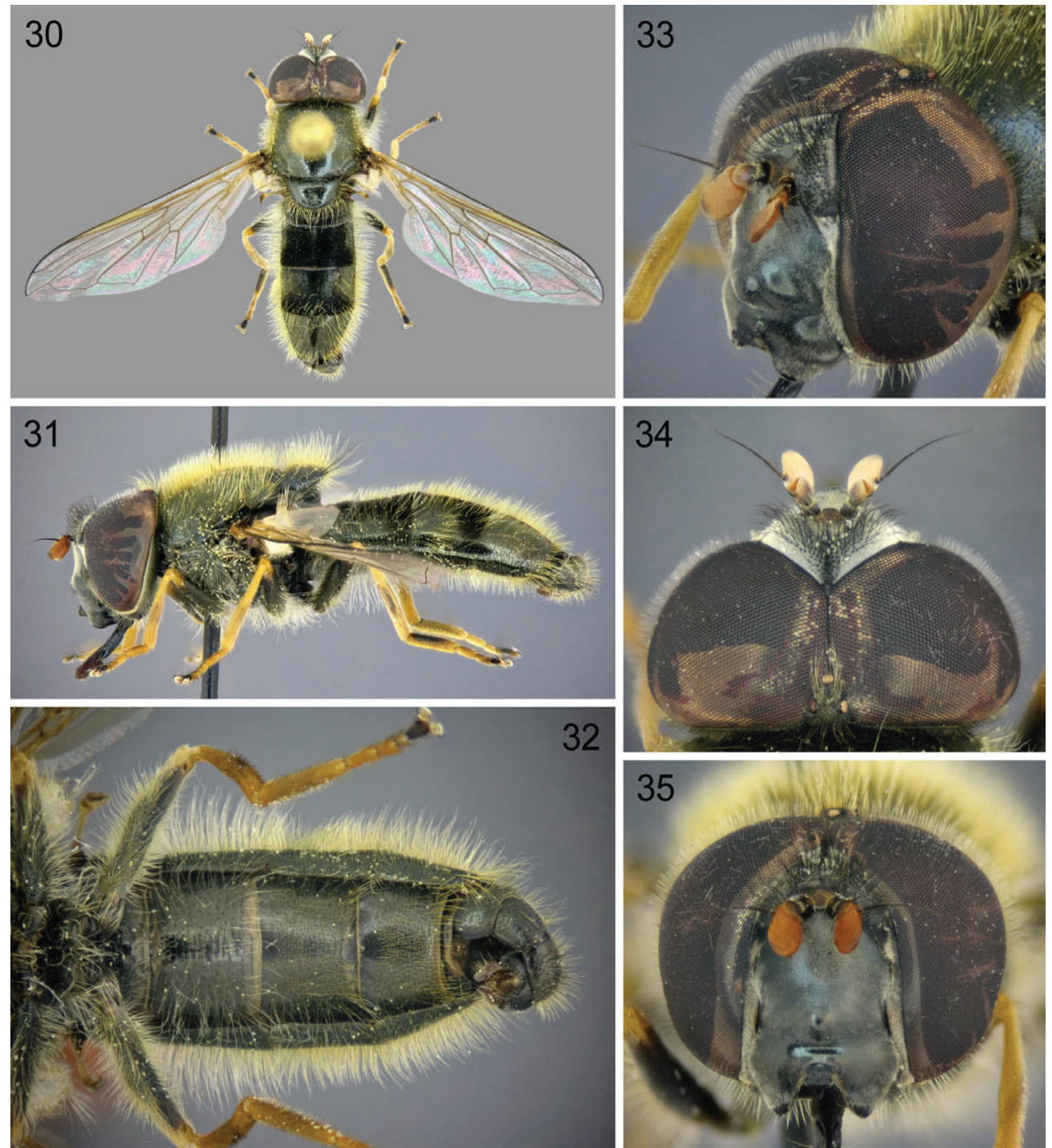

Figs 30-35. Cheilosia uviformis male: 30 - habitus, dorsal view; 31 - habitus, lateral view; 32 - abdomen, ventral view; 33 - head, anterolateral view; 34 - head, dorsal view; 35 - head, frontal view. 
Distribution: Belgium, Denmark, Great Britain, Finland, France, Germany, Ireland, Italy, Lithuania, the Netherlands, Norway, Serbia, Slovenia, Sweden, Switzerland (Peck, 1988; Verlinden, 1991; Maibach et al., 1992; Dirickx, 1994; Vujić, 1996; Nielsen, 1999; Stubbs \& Falk, 2002; Pakalniškis et al., 2006; De Groot \& Govedič, 2008; Bartsch et al., 2009 b; Reemer et al., 2009; Haarto \& Kerppola, 2014; Speight et al., 2018; Speight, 2020; Verlinden, 2020; Wakkie, 2020); Ukraine (first record).

Diagnosis. The Cheilosia uviformis male looks like the males of C. urbana (Meigen, 1822) and C. psilophthalma Becker, 1894, and it can also be confused with small specimens of C. rufimana Becker, 1894.

From C. urbana and C. psilophthalma it can be distinguished by: frons densely covered in microtrichia (fig. 34) (in others, frons covered in faint microtrichia, weakly shiny except the edges along the eyes); face almost entirely with fine but distinct pruinescence including the facial tubercle, only lowest edge of face shiny (in others, frons with facial tubercle and upper mouth-edge distinctly shiny, rarely the facial tubercle may also be finely pruinose); all tibiae entirely yellow or with very vague brownish smudge on each side of tibia (fig. 31) (in others, all tibiae yellow with black incomplete ring); abdomen entirely with pale pile, tergites 2 and 3 without short semi-adpressed macrotrichia posteromedially (in others, abdomen usually at least with a few black macrotrichia, tergites 2 and 3 with short semiadpressed macrotrichia posteromedially); sternites 2-4 dull (fig. 32) (in others, sternites 2-4 shiny).

Cheilosia uviformis can be easily distinguished from C. rufimana by katepisternum with upper and lower patches of pile widely separated (in C. rufimana, katepisternum with upper and lower patches of pile confluent).

Morphological characters of our specimens are completely consistent with those in Speight \& Claussen (1987: as Cheilosia argentifrons Hellen, 1914). Genitalia of both specimens have been prepared and compared with figures in Speight \& Claussen (1987: fig. 2, f, g) and Stubbs \& Falk (2002: Plate M, fig. 1, a-c).

Note. In Great Britain this species is listed under the UK Biodiversity Action Plan and qualifies as Data Deficient (Ball \& Morris, 2014).

Here we offer an updated key to Ukrainian Cheilosia males of the group D sensu Becker (1894), which have tibiae with pale parts.

\section{Key to males of Ukrainian Cheilosia species group D (tibiae with pale parts)}

$1 \quad$ Katepisternum with upper and lower patches of pile confluent.

- Katepisternum with upper and lower patches of pile widely separated.

Face width at the level of the antennal sockets exceed eye width at the same level.

C. morio (Zetterstedt, 1838)

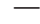

3

Face width at the level of the antennal sockets less than eye width at the same level.

C. proxima species group

Tergites covered in grey patches of microtrichia, which usually look like maculae. ............................... 4

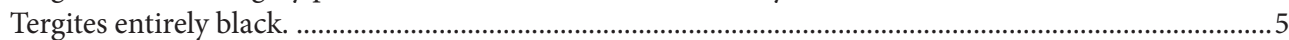
Compound eye with pale pile. C. semifasciata Becker, 1894

Compound eye with dark pile. C. fasciata Schiner \& Egger, 1853

Compound eye entirely pilose (lower part sometimes more sparcely). ..................................................... 6

Lower part of compound eye bare or with a single pile. ...................................................................... 12 Frons densely covered in pale-grey microtrichia (fig. 34) as well as orbital strip (this is clearly visible against the general background of the face); sternites 2-4 dull (fig. 32). ............ uviformis Becker, 1894 Frons shiny or with faint pruinescence (mostly along eye margins), also faintly pruinose on orbital strip; sternites $2-4$ shiny.

Compound eye with pale pile; abdomen slender, with almost parallel sides. ........................................ 8

Compound eye with dark pile; abdomen oval, usually wider. …............................................................. 10

Arista with distinct short microtrichia. ............................................................... . mutabilis (Fallén, 1817)

Arista seems bare (with very short microtrichia). 
10 Abdomen with the largest width at the posterior margin of tergite 3; tergite 4 with adpressed short black seta-shape macrotrichia along central axis; legs dark, fore and mid tibiae with weak brown bases and apexes, hind tibia black with indistinct brown base.

C. carbonaria Egger, 1860

- $\quad$ Abdomen with the largest width at the posterior margin of tergite 2; tergite 4 with erect and (or) semiadpressed macrotrichia along central axis; all tibiae yellow or pale brown with dark ring, or mostly black with yellow or brown bases and apexes.

11 Mesonotum black, usually with a bluish tinge, predominantly with black pile; tergite 5 dull in contrast with shiny tergite 4 .......................................................................................... C. cynocephala Loew, 1840 Mesonotum black, usually without a bluish tint, predominantly with pale pile or with black and pale pile mixed; tergite 5 shiny as well as tergite 4 .

C. vernalis (Fallén, 1817)

Tibiae black with pale parts; tarsomeres of all tarsi black dorsally and laterally.

.. C. sootryeni Nielsen, 1970

Tibiae pale with black parts (sometimes entirely pale); fore and mid tarsi not entirely black. ............. 13

13 Scutellum with pile and setae half or slightly more than half as long as scutellum (fig. 10), at that scutellum often without setae; abdomen more oval, distinctly with largest width at the posterior edge of tergite 2 (fig. 9); fore tarsus black (fig. 12) (tarsomeres 1+2 pale laterally and ventrally), mid tarsus black except first tarsomere usually pale (fig. 13); hind tibia with weak, incompletely developed dark ring (fig. 11), which may be reduced. C. fraterna (Meigen, 1830) Scutellum with pile and setae at least as long as scutellum (fig. 2); abdomen more slender, elongated-oval with almost parallel sides of tergite 3 (fig. 1); fore and mid tarsi with tarsomeres 1-3 entirely pale (figs $4,5)$ (first tarsomere of fore tarsus may be darkened dorsally); hind tibia usually with distinct black ring occupying almost half of tibia (fig. 3). C. bergenstammi Becker, 1894

\section{Subtribe Pelecocerina}

\section{Pelecocera (Chamaesyrphus) scaevoides (Fallén, 1817) (figs 36-41)}

Material examined. Ukraine. Ivano-Frankivsk Region: Zelena env., 48.413701 N 24.379997 E, alpine meadow, 20.06.2018, 3 ơ, 5 ९ (V. Shparyk).

Distribution: Andorra, Austria, Belgium, Bulgaria, Croatia, the Czech Republic, Estonia, Finland, France, Germany, Great Britain (Scotland), Greece, Hungary, Italy, Latvia, Liechtenstein, Luxembourg, Moldova, Montenegro, the Netherlands, Norway, Poland, Romania, Serbia, the Slovak Republic, Slovenia, Spain, Sweden, Switzerland; Russia (European part, Yakutia, the Far East); Transcaucasia (the Republic of Georgia), Turkey (Bańkowska, 1963; Peck, 1988; Verlinden, 1991; Maibach et al., 1992; Kuznetzov, 1993; Dirickx, 1994; Belcari et al., 1995; Holinka \& Mazánek, 1997; Wolff, 1998; Nielsen, 1999; Carrières, 2001 b; Stubbs \& Falk, 2002; Stănescu \& Pârvu, 2005; Gammelmo \& Nielsen, 2008; Mielczarek, 2009-2020; Reemer et al., 2009; De Grootet al., 2010; Tóth, 2011, 2014; Williams et al., 2011; Haarto \& Kerppola, 2014; Saribiyik, 2014; Ricarte \& Marcos-García, 2017; Barkalov \& Mutin, 2018; Miličić et al., 2018; Speight et al., 2018; Mengual et al., 2020; Speight, 2020; Wakkie, 2020); Ukraine (first record).

Diagnosis. Both sexes of $P$. scaevoides are similar to P. caledonica (Collin, 1940) in sharingthe following characters: anterodorsal portion of anepisternum without pile or setae, at most with thick microtrichia; frons, at the level of the antennal sockets, narrower than the width of an eye at the same level (figs 40,41); propleural and mesopleural sclerites entirely covered in grey microtrichia (fig. 38); lateral arms of the lunule (extending round the dorsal edge of the antennal sockets) entirely shining, or entire lunule shining. From the male $P$. caledonica the male of $P$. scaevoides differs by: face entirely covered in microtrichia (figs 39, 40) (in P. caledonica, face with median black vitta shining); the length of postocular orbits is dorsally, at the inner end of the eye, shorter than a posterior ocellus (in P. caledonica, the length of the postocular orbits is dorsally, at the inner end of the eye, longer than a posterior ocellus); wing entirely covered in microtrichia (in P. caledonica, basal medial 

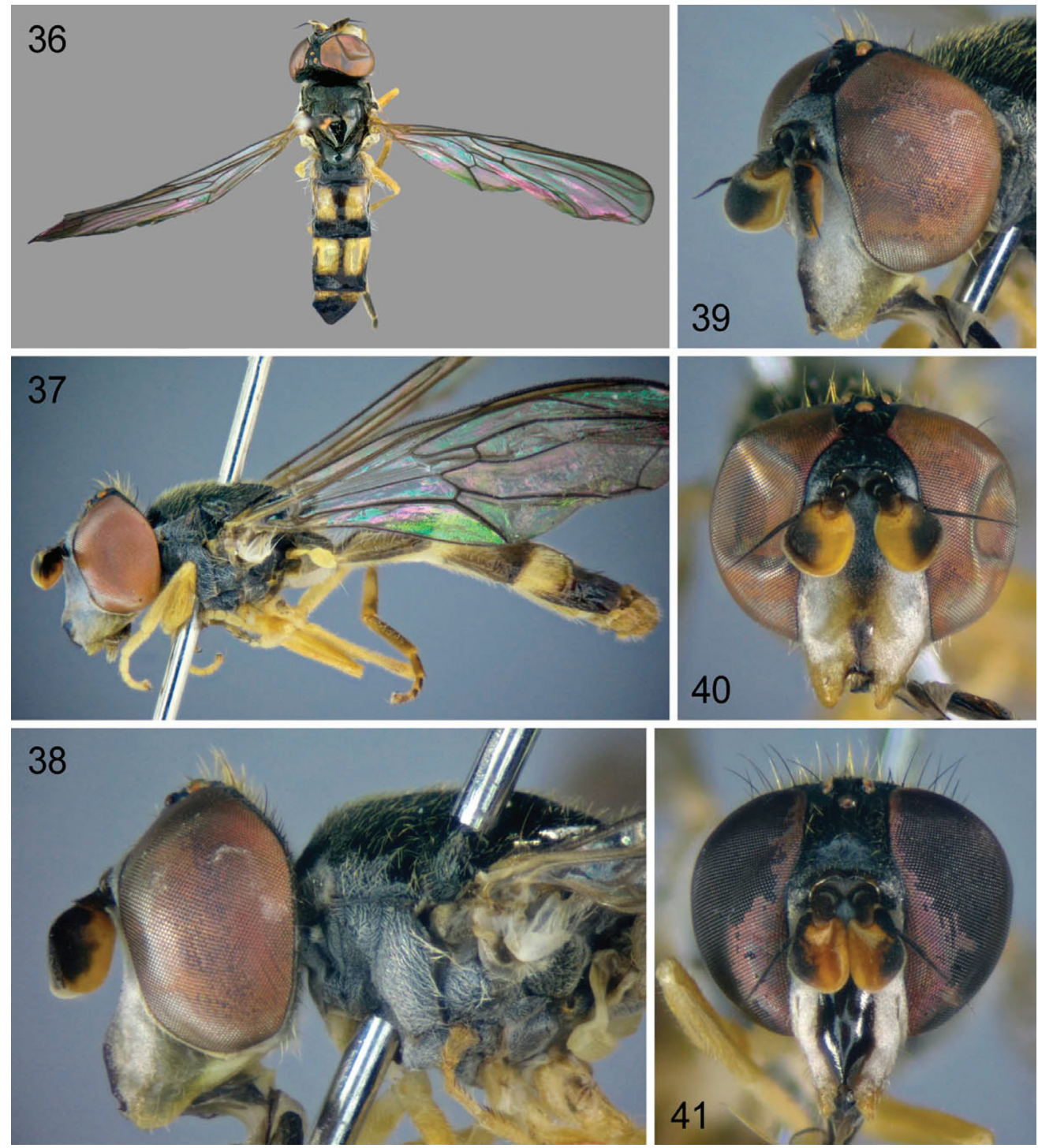

Figs 36-41. Pelecocera (Chamaesyrphus) scaevoides: 36 - male habitus, dorsal view; 37 - male habitus, lateral view; 38 - male head and thorax, lateral view; 39 - male head, anterolateral view; 40 - male head, frontal view; 41 - female head, frontal view.

$(\mathrm{bm})$ and posterior cubital cells (cup) of the wing each with an area bare of microtrichia); tarsomeres $3+4$ of fore and mid tarsi entirely pale, as well as the tibiae (fig. 37 ) (in P. caledonica, tarsomeres $3+4$ of fore and mid tarsi brown, darker than the tibiae); lunule with median triangle entirely, or partly, covered in dense, grey microtrichia (in P. caledonica, lunule entirely undusted, brightly shining) (Speight \& Sarthou, 2017).

The female of Pelecocera scaevoides (fig. 41) can be separated from the female of $P$. caledonica by: at the inner corner of the eye, on the dorsal surface of the head, the distance between the posterior margin of the eye and the posterior margin of the head is slightly greater than the length of a posterior ocellus, but distinctly less than $1.5 \mathrm{x}$ as long as a posterior ocellus (in $P$. caledonica, the distance between the posterior margin of the eye and the posterior margin of the head is slightly greater than $1.5 \mathrm{x}$ the length of a posterior ocellus); wing entirely covered in microtrichia (in $P$. caledonica, basal medial ( $\mathrm{bm}$ ) and posterior cubital cells (cup) of the wing each with an area bare of microtrichia) (Speight \& Sarthou, 2017). 
Note. In Great Britain this species is listed under the UK Biodiversity Action Plan and qualified as Nationally Scarce (Ball \& Morris, 2014).

\section{Subfamily Syrphinae}

Dasysyrphus pauxillus (Williston, 1887) (figs 42-46)

Material examined.Ukraine. Kyiv Region: Dibrova env., 50.194443 N 30.203628 E, 25.04.2010, 1 o" (M. Zaika); Irpin env., 50.50 N 30.28 E, Lyubka River floodplain forest, 20.04.2019, 1 O' (A. Prokhorov).

Distribution: Austria, Belgium, the Czech Republic, Denmark, Finland, France, Germany, Great Britain, Greece, Italy, North Macedonia, the Netherlands, Norway, Poland, Romania, Serbia, the Slovak Republic, Spain, Sweden, Switzerland; Russia (European part, Siberia); Nearctic Region (from Alaska to California and across to New York) (Doczkal, 1996; Holinka \& Mazánek, 1997; Nielsen, 1999; Stănescu \& Pârvu, 2005; Bartsch et al., 2009 a; Krpač et al., 2009; Mielczarek, 2009-2020; Reemer et al., 2009; Ball et al., 2011; Williams et al., 2011; Locke \& Skevington, 2013; Haarto \& Kerppola, 2014; Ricarte \& Marcos-García, 2017; Barkalov \& Mutin, 2018; Speight et al., 2018; Speight, 2020; Wakkie, 2020); Ukraine (first record).

Diagnosis.Dasysyrphus pauxillus is very similar in appearance to D. lenensis Bagatshanova, 1980, D. nigricornis (Verrall, 1873) and D. pinastri (De Geer, 1776) in having yellow paired maculae on tergites $3+4$ not reaching the lateral margin of tergites (fig. 43). The
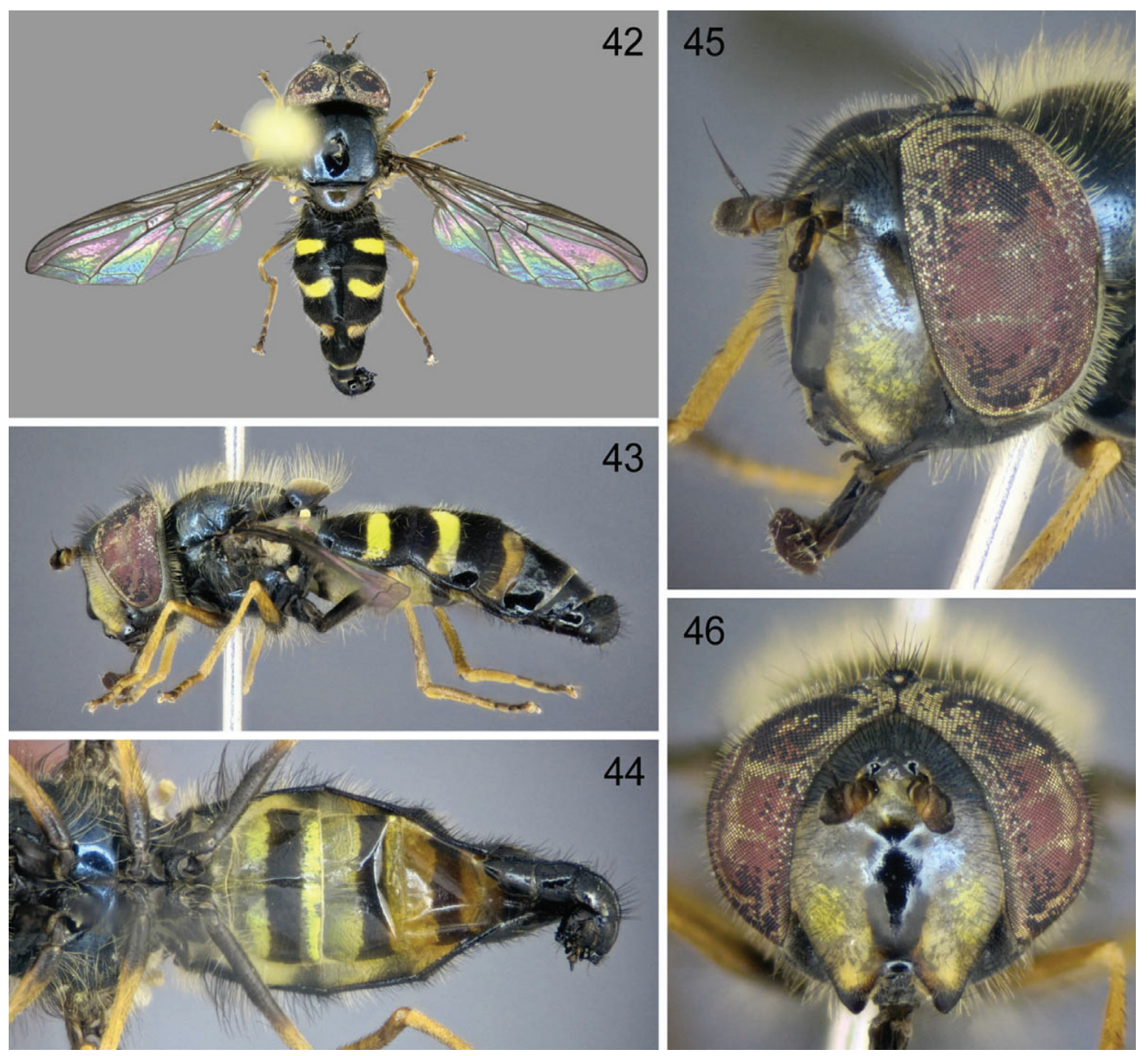

Figs 42-46. Dasysyrphus pauxillus male: 42 - habitus, dorsal view; 43 - habitus, lateral view; 44 - abdomen, ventral view; 45 - head, anterolateral view; 46 - head, frontal view. 
male of D. pauxillus differs from the males of $D$. lenensis and $D$. pinastri by: mesonotum predominantly covered in pale pile (fig. 43) (in others, mesonotum predominantly covered in black pile); the lower part of the face is covered in black pile (figs 45, 46), or with pale and black pile mixed (in others, the lower part of the face is covered in pale pile); last antennal segment yellowish ventrally, antenna completely dark in D. lenensis and D. pinastri, tergite 2 with black macrotrichia on the side margin (in others, tergite 2 with pale macrotrichia on the side margin, only with black ones at the hind corners of the tergite) (Bartsch et al., 2009 a; Van Veen, 2010). The genitalia of D. pauxillus, D. lenensis and D. pinastri are clearly different in the structure of the gonostylus and aedeagus (Doczkal, 1996: figs 15-22).

Dasysyrphus pauxillus differs from $D$. nigricornis by: frons with an angle of approximation of eyes blunt (fig. 42) (in D. nigricornis, frons with an angle of approximation of eyes acute); eyes meeting over a distance distinctly shorter than the frons length (fig. 46) (in D. nigricornis, eyes meeting over a distance not shorter than the frons length) (Bartsch et al., 2009 a).

Genitalia of our specimen with a triangular projection of distiphallus, projecting ventrally even more than shown in the figures in Doczkal (1996: fig. 16), Bartsch et al. (2009 a: page 190) and Locke \& Skevington (2013: fig. 14D).

Note. There are many Holarctic species that have a habitus similar to pauxillus and their concepts are even more confusing (Locke \& Skevington, 2013).

\section{Epistrophe cryptica Doczkal and Schmid, 1994 (figs 47-52)}

Material examined.Ukraine. Ivano-Frankivsk Region: Khom'yakivka env., 48.861022 N 24.819297 E, edge of deciduous forest, 26.05.2019, 1 Q (V. Shparyk).

Distribution:uncertain, due to confusion with other related species until recently. Confirmed from Austria, Belgium, the Czech Republic, Denmark, Estonia, Finland, France, Germany, Hungary, the Netherlands, Norway, Poland, ?Serbia, Sweden, Switzerland; Russia (European part, Siberia, the Far East); Japan (Holinka \& Mazánek, 1997; Nielsen, 1999; Mielczarek, 2009-2020; Reemer et al., 2009; Tóth, 2011; Haarto \& Kerppola, 2014; Barkalov \& Mutin, 2018; Speight et al., 2018; Van Steenis et al., 2019; Speight, 2020; Wakkie, 2020); Ukraine (first record).

Diagnosis. The Epistrophe cryptica female is most similar to the female of E. obscuripes (Strobl, 1910) (figs 53-58) in sharing the following characters: basal medial ( $\mathrm{bm}$ ) cell of wing entirely covered in microtrichia; mesoscutum mostly brightly shining, without distinct pruinescence dorsally; tergite 5 partly black; scutellum with only yellow macrotrichia or with just a few black macrotrichia along hind margin; frons entirely black (figs $51,52,57,58$ ); anterior side of hind tibia entirely or partly with yellow macrotrichia (figs 49, 55). Epistrophe cryptica can be distinguished from E. obscuripes by: arista yellow, at least in basal half (fig. 51) (in E. obscuripes, arista entirely black, as in fig. 57); anterior side of hind femur with black macrotrichia apically (fig. 48) (in E. obscuripes, anterior side of hind femur almost only with yellow macrotrichia, as in fig. 54); anterior side of hind tibia covered in a mixture of black and yellow macrotrichia (fig. 49) (in E. obscuripes, anterior side of hind tibia entirely covered in yellow macrotrichia, as in fig. 55).

The species is also very similar in appearance to E. melanostoma (Zetterstedt, 1843), E. nitidicollis (Meigen, 1822) and E. olgae Mutin, 1990. From E. nitidicollis and E. olgae it differs by: wing entirely covered in microtrichia (in others, wing with basal medial $(\mathrm{bm})$ cell $20 \%$ or more bare of microtrichia); scutellum with only yellow macrotrichia or with just a few black macrotrichia along hind margin (in others, at least one third of the scutellum with black macrotrichia); frons entirely black with gray pruinescence that do not look like separate maculae (figs 51,52) (in others, frons with yellow anterior part and usually with two well developed yellowish-gray or golden-yellow maculae of pruinescens; in E. olgae, frons entirely with dense pruinescence except for the anterior part, and the maculae 

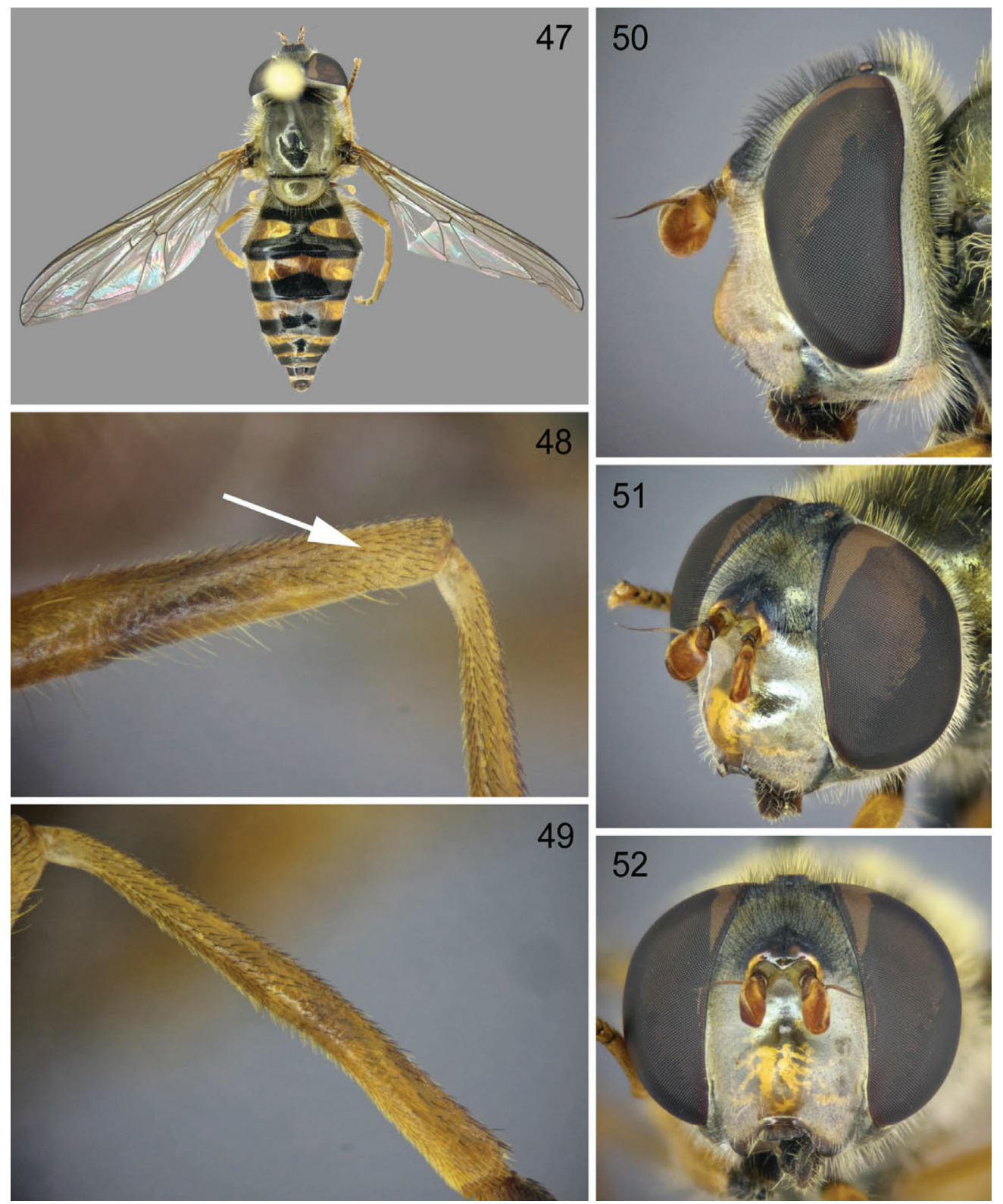

Figs 47-52. Epistrophe cryptica female: 47 - habitus, dorsal view; 48 - apex of the hind femur, lateral view (arrow shows black macrotrichia); 49 - hind tibia, lateral view; 50 - head, lateral view; 51 - head, anterolateral view; 52 - head, frontal view.

along the compound eye margin often merge almost into a continuous band). Additionally, E. cryptica differs from E. nitidicollis by the yellow arista, at least in basal half (fig. 51) (in E. nitidicollis, the arista is black, rarely it can be brownish or yellowish).

Epistrophe cryptica is very similar to E. melanostoma in having: wing entirely covered in microtrichia; scutellum with only yellow macrotrichia or with just a few black macrotrichia along the hind margin; anterior surface of hind femur with black macrotrichia on apical third or more of its length (fig. 48). From E. melanostoma it can be separated by: frons entirely black (figs 51,52) (in E. melanostoma, frons with yellow anterior part); hind tibia with the anterior side covered in a mixture of black and yellow macrotrichia (fig. 49) (in E. melanostoma, anterior side of hind tibia entirely with black macrotrichia). 

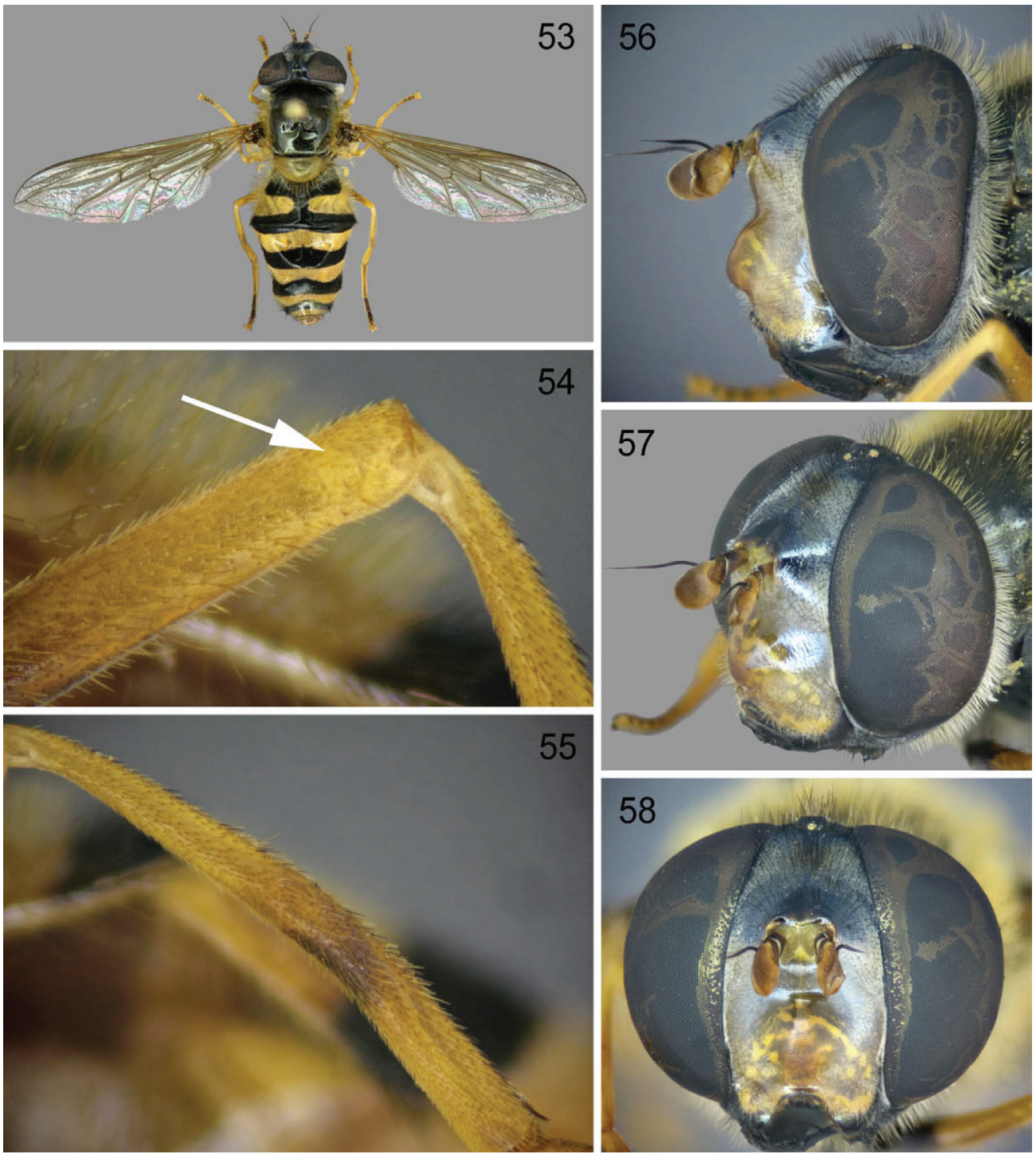

Figs 53-58. Epistrophe obscuripes female (Moscow Region, Russia): 53 - habitus, dorsal view; 54 - apex of the hind femur, lateral view (arrow shows yellow macrotrichia); 55 - hind tibia, lateral view; 56 - head, lateral view; 57 - head, anterolateral view; 58 - head, frontal view.

\section{Melangyna quadrimaculata (Verrall, 1873) (figs 59-63)}

Material examined.Ukraine. Kyiv Region: Kyiv, 50.351462 N 30.481535 E, Theophania Park env., edge of deciduous forest, 28.03.2016, on flowers of Salix sp., 1 @ (M. Zaika).

Distribution:Belarus, Belgium, Bulgaria, Croatia, the Czech Republic, Denmark, Estonia, Finland, France, Germany, Great Britain, Hungary, Ireland, Italy, Latvia, Lithuania, the Netherlands, Norway, Poland, Romania, the Slovak Republic, Slovenia, Sweden, Switzerland; Russia (European part, Eastern Siberia, the Far East); Japan (Bańkowska, 1963; Peck, 1988; Verlinden, 1991; Kuznetzov, 1993; Dirickx, 1994; Belcari et al., 1995; Holinka \& Mazánek, 1997; Wolff, 1998; Nielsen, 1999; Stubbs \& Falk, 2002; Stănescu \& Pârvu, 2005; Pakalniškis et al., 2006; De Groot \& Govedič, 2008; Mielczarek, 2009-2020; Reemer et al., 2009; Tóth, 2011, 2014; Borodin \& Borodina, 2014; Haarto \& Kerppola, 2014; Barkalov \& Mutin, 2018; Speight et al., 2018; Speight, 2020; Wakkie, 2020); Ukraine (first record). 
Diagnosis. The Melangyna quadrimaculata female is similar to the female of M. barbifrons (Fallén, 1817) by its shining frons without pruinescence (figs 61-63), or with only rudimentary pruinescence. It can be separated from $M$. barbifrons by tergites without pale maculae, uniformly dark except for patches of paler pruinescens (fig. 59) (tergite 3, at the
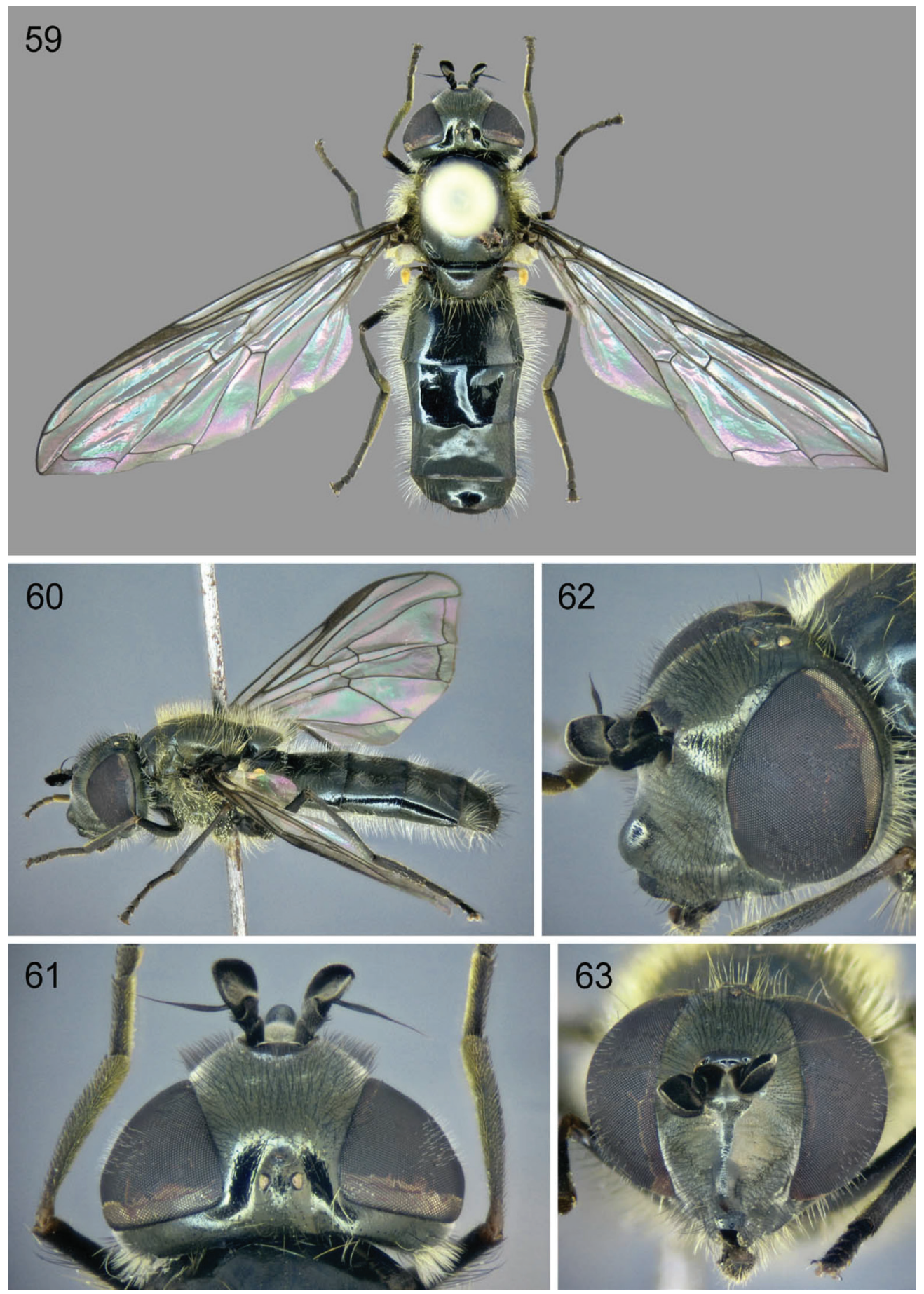

Figs 59-63. Melangyna quadrimaculata female: 59 - habitus, dorsal view; 60 - habitus, lateral view; 61 head, dorsal view; 62 - head, anterolateral view; 63 - head, frontal view. 
most, with a pair of vestigial pale maculae) (in M. barbifrons, tergites 2-4 each with a pair of pale maculae (Bartsch et al., 2009 a; Speight \& Sarthou, 2017).

Melanistic females of $M$. lasiophthalma (Zetterstedt, 1843) are frequently misidentified as females of M. quadrimaculata (Speight, 2020).

\section{Xanthogramma dives (Rondani, 1857) (figs 64-65)}

Material examined. Ukraine. Zakarpattia: Kamianytsia env., 48.70 N 22.43 E, deciduous forest, 11.05.2017, 1 ○; Vynogradiv env., 48.144001 N 23.071348 E, 26.06-18.07.2018, Malaise trap, 2 o (A. Varga); Rivne Region: Bushcha env.: Mizotskyi Kriazh, 50.30 N 26.30 E, deciduous forest, 20-22.05.2019, 2 o; Illyashivka env., 50.277 N 26.281 E, 21.05.2019, edge of deciduous forest, 2 o'; Kyiv Region: Potashnia env., 50.688 N 29.736 E, mixed forest, 9.05.2016, on flowers of Sorbus aucuparia, 1 o'; Mygalky env., 50.66 N 29.50 E, edge of mixed forest near Teteriv River floodplain, 21-22.05.2016, 6 ơ, 2 ९, 20.05.2017, 2 o", 1 o, 27.05.2018, 1 ᄋ; Irpin env.: $50.51 \mathrm{~N} 30.27 \mathrm{E}$, edge of mixed forest along the railway, 5.06.2015, 1 \&, 25.06.2017, 1 o, 26.06.2018, 1 o; 50.51 N 30.26 E, edge of mixed forest near Irpin River floodplain, 23.08.2016, 1 ơ; Kotsiubynske env., 50.47 N 30.30 E, clearing in mixed forest, 17.05.2017, 2 o'; Lisnyky env., Golosiivskyi National Nature Park, 50.29 N 30.54 E, deciduous forest, 17.08.2017, 1 ○; 50.296 N 30.535 E, 3.05.2019, 2 ơ; Zavorychi env., 50.68 N 31.09 E, deciduous forest, 16.07.2015, 1 ơ, 1 o (A. Prokhorov); Chernihiv Region: Nizhyn, 51.05 N 31.88 E, Hrafskyi Park, 10.05.2018, 1 ○' (V. Kavurka); Morivsk, 51.088 N 30.882 E, in the garden, 14.07.2018, 1 o (A. Prokhorov).

Distribution: at present uncertain, due to confusion until recently with both $X$.pedissequum and X. stackelbergi, but known fromAndorra, the Czech Republic, France, Germany, Greece, Hungary, Italy, Montenegro, the Netherlands, Norway, Poland, Portugal, European Russia, Serbia, the Slovak Republic, Slovenia, Spain, Sweden, Switzerland;Transcaucasia (the Republic of Georgia) (Belcari et al., 1995; Doczkal et al., 2002; De Groot \& Govedič, 2008; Mielczarek, 2009-2020; Tóth, 2011; Van Eck, 2011; Van Steenis, 2011; Ssymank, 2012; Van Steenis et al., 2015; Ricarte \& Marcos-García, 2017; Nedeljković et al., 2018; Speight et al., 2018; Prokhorov, 2019; Van Steenis et al., 2019; Mengual et al., 2020; Speight, 2020; Wakkie, 2020); Ukraine (first record).
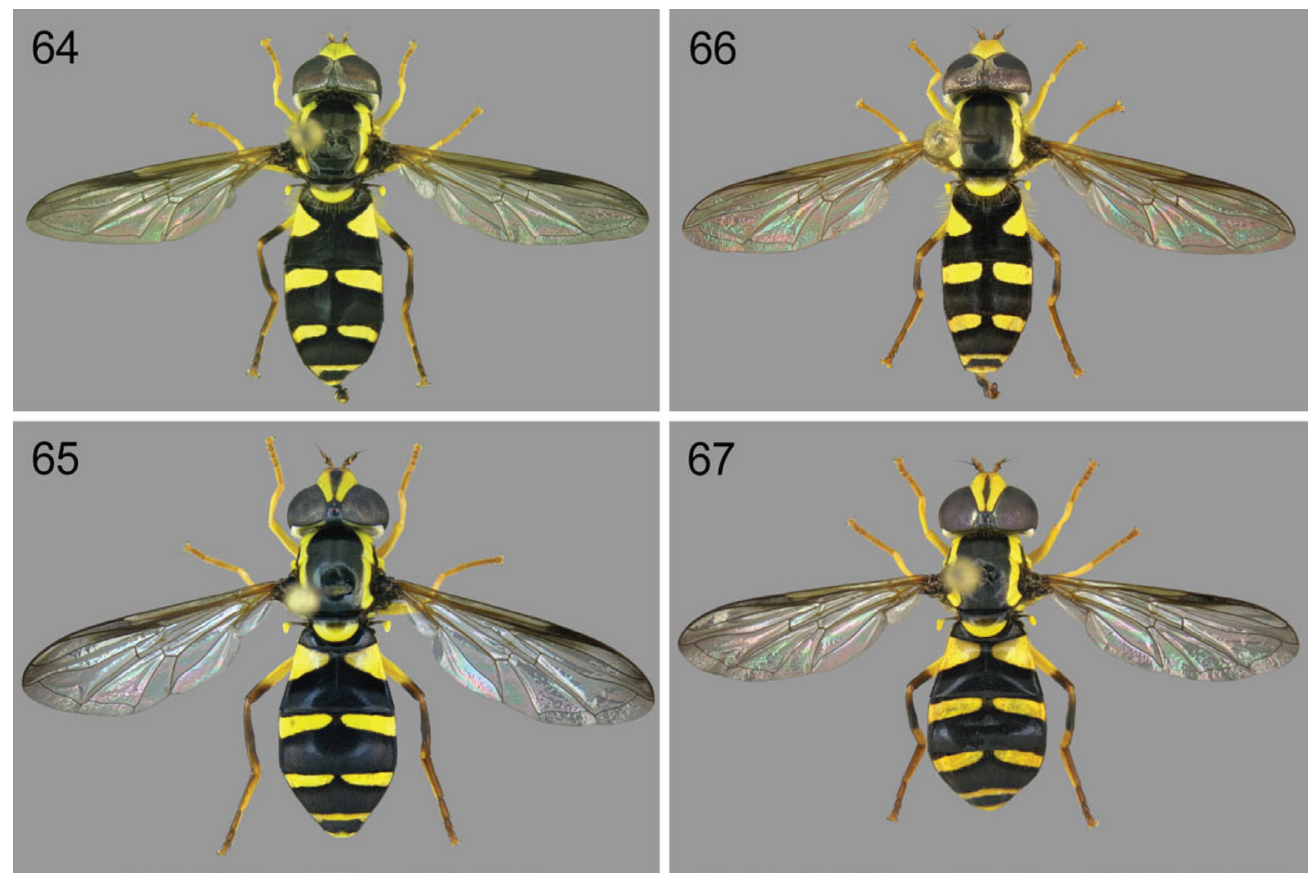

Figs 64-67. Xanthogramma dives from Chernihiv (64) and Kyiv (65) Regions, and X. stackelbergi $(66,67)$ from Zakarpattia, habitus, dorsal view: 64, 66 - males; 65, 67 - females. 
Diagnosis. Within the genus Xanthogramma, X. dives, X. pedissequum and X. stackelbergi are very similar in appearance. They share the following characters: tergite 2 wider than long; alula entirely covered in microtrichia; eye pilosity very sparse, shorter than the diameter of the anterior ocellus; hind femora black on the apical fourth. Xanthogramm adives can be easily separated from $X$. pedissequum by the thorax with more than two yellow maculae laterally (in $X$. pedissequum, thorax with one or two yellow maculae laterally). From the most similar $X$. stackelbergi (figs 66,67), both sexes of $X$. dives can be distinguished by wing cells $r_{1}$ and $r_{2+3}$ darkened in the apical part (figs 64, 65) (in X. stackelbergi, wing cells $r_{1}$ and $r_{2+3}$ hyaline in the apical part, as on figs 66,67 ). These characters are based on Nedeljković et al. (2018). Additionally, X. dives female differs from X. stackelbergi by a black median vitta on the frons that usually expands towards the lunule (fig. 65) (in $\mathrm{X}$. stackelbergi, a black median vitta on the frons usually tapers towards the lunule, as on fig. 67) (according Speight \& Sarthou, 2017).

Note. Until recently, $X$. dives was erroneously confused with the two similar species X. pedissequum (Harris, 1776) and X. stackelbergi Violovitsh, 1975, and this taxon was not included in the most of European species lists before Speight \& Sommaggio (2010), who designated the $X$. dives lectotype.

We are very grateful to Volodymyr Roshko (Uzhhorod National University, Uzhhorod), for his kind assistance in organizing collecting trips to Zakarpattia in 2017-2018, and Oksana Golovko (National Park Dermansko-Ostrozkyi, Rivne Region) for her assistance in organizing and conducting expeditionary trips to the National Park in 2018-2019. The authors are grateful to Myroslav Zaika for material from Kyiv Region. We thank Anatoly Barkalov (Institute of Systematics and Ecology of Animals, RAS, Novosibirsk) for useful comments on species of the genus Cheilosia. The authors also very thank Valery Korneyev (Institute of Zoology of NAS of Ukraine, Kyiv) for valuable scientific and editorial comments. We very appreciate two anonymous referees for critical notes and corrections to improve this manuscript.

\section{References}

Ball, S. G., Morris, R. K. A., Rotheray, G. E., Watt, K. R. 2011. Atlas of the hoverflies of Great Britain (Diptera, Syrphidae). Biological Records Centre, Wallingford, 1-184.

Ball, S. G., Morris, R. K. A. 2014. A review of the scarce and threatened flies of Great Britain. Part 6: Syrphidae. Species status, No. 9, Joint Nature Conservation Committee, Peterborough, 1-130.

Bańkowska, R. 1963. Część XXVII. Muchówki - Diptera. Zeszyt 34. Syrphidae. In: Burakowski, B. et al., eds. Klucze do oznaczania owadów Polski [Polski związek entomologiczny. Nr 42 serii kluczy]. — Państwowe wydawnictwo naukowe, Warszawa, 1-236 [In Polish].

Barkalov, A. V. 1993. Hover flies of the genus Cheilosia Meigen, 1822 (Diptera, Syrphidae) of the Caucasus. Entomological review, 72 (3): 698-727 [In Russian].

Barkalov, A. V., Mutin, V. A. 2018. Checklist of the hover-flies (Diptera, Syrphidae) of Russia. Euroasian Entomological Journal, 17 (6), 466-510.

Bartsch, H., Binkiewicz, E., Rådén, A., Nasibov, E. 2009 a. In: Engström, C. (Chefredaktör), Nationalnyckeln till Sveriges flora och fauna. DH 53 a. Tvåvingar: Blomflugor: Syrphinae. Diptera: Syrphidae: Syrphinae. ArtDatabanken, Sveriges lantbruksuniversitet, Uppsala, 1-406.

Bartsch, H., Binkiewicz, E., Klintbjer, A., Rådén, A., Nasibov, E. 2009 b. Tvåvingar: Blomfl ugor. Diptera: Syrphidae: Eristalinae, Microdontinae. Denna volym omfattar samtliga nordiska arter. In: Engström, C. (Chefredaktör), Nationalnyckeln till Sveriges flora och fauna. DH 53 b. ArtDatabanken, Sveriges lantbruksuniversitet, Uppsala, 1-478.

Becker, Th. 1894. Revision der Gattung Chilosia Meigen. Nova Acta Physico-Medica Academiae Caesareae Leopoldino-Carolinae Naturae Curiosum, 62 (3), 194-521.

Belcari, A., Daccordi, M., Kozanek, M., Munari, L. Raspi, A., Rivosecchi, L. 1995. Diptera Platypezoidea, Syrphoidea. In: Minelli, A., Ruffio, S., La Posta, S., eds. Checklist delle Specie della Fauna Italiana, 70, Calderini, Bologna, 1-25.

Borodin, O. I., Borodina, O. A. 2014. Taxonomical structure of the hoverflies (Diptera: Syrphidae) of the Belarus fauna. Herald of BaranovichiStateUniversity (BarSU). Series Biological Sciences. Agricultural Sciences, 2 , 7-12 [In Russian].

Carrières, E. 2001 a. Dipterological note: update of the faunistic list of the hoverflies (Diptera, Syrphidae) from Luxembourg. Bulletin de la Société des naturalistes luxembourgeois, 101, 99-110 [In French]. 
Carrières, E. 2001 b. Dipterological note: first additions to the fauna list of hoverflies (Diptera, Syrphidae) of Luxembourg. Bulletin de la Société des naturalistes luxembourgeois, 102, 97-102 [In French].

Claussen, C., Speight, M. C. D. 1988. Zur Kenntnis von Cheilosia vulpina (Meigen, 1822) and Cheilosia nebulosa Verrall, 1871 (Diptera, Syrphidae). Bonner zoologische Beiträge, 39 (1), 19-28 [In German].

Cumming, J. M. \& Wood, D. M. 2017. Adult morphology and terminology. In: Kirk-Spriggs, A. H. \& Sinclair, B. J., eds., Manual of Afrotropical Diptera. Volume 1. Introductory chapters and keys to Diptera families. Suricata 4, Pretoria, South Africa, 89-133.

De Groot, M., Govedič, M. 2008. Checklist of the hoverflies (Diptera: Syrphidae) of Slovenia. Acta entomologica Slovenica, 16 (1), 67-86.

De Groot, M., Luštrik, R., Faasen, T., Fekonja, D. 2010. Additions and omissions to the list of hoverfly fauna (Diptera: Syrphidae) of Slovenia. Acta entomologica Slovenica, 18 (2), 77-86.

Dirickx, H. G. 1994. Atlas des Diptères syrphides de la région méditerranéenne. 75, 1-318.

Doczkal, D. 1996. Hoverflies from Germany: first records and little known species (Diptera, Syrphidae). Volucella, 2 (1/2), 36-62.

Doczkal, D., Claußen, C., Ssymank, A. 2002. First supplement and corrections to the check list of the hoverflies of Germany (Diptera, Syrphidae). Volucella, 6, 167-173.

Gammelmo, Ø., Nielsen, T. R. 2008. Further records of Hoverfly species (Diptera, Syrphidae) in Norway. Norwegian Journal of Entomology, 55, 19-23.

Haarto, A., Kerppola, S. 2014. Checklist of the family Syrphidae (Diptera) of Finland. In: Kahanpää, J., Salmela, J., eds. Checklist of the Diptera of Finland, ZooKeys, 441, 233-249. doi: 10.3897/zookeys.441.7251

Holinka, J., Mazánek, L. 1997. Syrphidae. In: Chvála, M., ed. Check List of Diptera (Insecta) of the Czech and Slovak Republics, Karolinum Press, Charles University, Prague, 60-66.

Krpač, V. T., Vujić, A., Šimić, S., Radenković, S., Lazarevska, S. 2009. Revision of the genus Dasysyrphus Enderlein, 1938 (Diptera: Syrphidae) in the fauna of Macedonia. Kragujevac Journal of Science, 31, 103-108.

Kuznetsov, S. Yu. 1992. The first instar larvae of the subfamily Pipizinae and Eristalinae (Diptera, Syrphidae). Daba un muzejs, 4, 24-43 [In Russian].

Kuznetsov, S. Yu. 1993. A checklist of Latvian, Lithuanian and Estonian hover flies (Diptera, Syrphidae). An International Journal of Dipterological Research, 4 (1-2), 35-47.

Lezhenina, I. P. 1993. The hoverflies (Diptera, Syrphidae) of the left-bank Ukraine. The Kharkov Entomological Society Gazette, 1 (1), 59-65 [In Russian].

Locke, M. M., Skevington, J. H. 2013. Revision of Nearctic Dasysyrphus Enderlein (Diptera: Syrphidae). Zootaxa, 3660 (1), 1-80.

Maibach, A., Goeldlin de Tiefenau, P., Dirickx, H. G. 1992. Check list of the Syrphidae occuring in Switzerland. Miscellanea faunistica Helvetiae, 1, 1-51 [In French].

Mengual, X., Ståhls, G., Rojo, S. 2008. First phylogeny of predatory flower flies (Diptera, Syrphidae, Syrphinae) using mitochondrial COI and nuclear 28S rRNA genes: conflict and congruence with the current tribal classification. Cladistics, 24, 543-562.

Mengual, X., Bot, S., Chkhartishvili, T., Reimann, A., Tormann, J., von der Mark, L. 2020. Checklist of hover flies (Diptera, Syrphidae) of the Republic of Georgia. ZooKeys, 916, 1-123.

Mielczarek, Ł. 2009 (2009-2020). List of species Syrphidae of Poland (Diptera, Syrphidae). Available from: http://syrphidae.insects.pl/checklist.php?lang=en (Accessed: April 4, 2020).

Miličić, M., Janković, M., Tot, T., Nedeljković, Z., Popov, S., Ivošević, B., Radenković, S., Vujić, A. 2018. New findings of hoverfly fauna (Diptera: Syrphidae) of the Western part of Serbia (Zlatibor and Raška Districts). Acta entomologica Serbica, 23 (2), 43-66.

Nedeljković, Z., Ricarte, A., Šašić Zorić, L., Đan, M., Obreht Vidaković, D., Vujic, A. 2018. The genus Xanthogramma Schiner, 1861 (Diptera: Syrphidae) in southeastern Europe, with descriptions of two new species. The Canadian Entomologist, 150, 440-464.

Nielsen, T. R. 1999. Check-list and distribution maps of Norwegian Hoverflies, with description of Platycheirus laskai nov.sp. (Diptera, Syrphidae). NINA Fagrapport, 35, 1-99.

Pakalniškis, S., Bernotienė, R., Lutovinovas, E., Petrašiūnas, A., Podėnas, S., Rimšaitė, J., Sæther, O. A., Spungis, V. 2006. Checklist of Lithuanian Diptera. New and rare for Lithuania insect species, 18, 16-154.

Peck, L. V. 1988. Family Syrphidae. In: Soós, Á., Papp, L., eds. Catalogue of Palaearctic Diptera, 8 (SyrphidaeConopidae), Elsevier Science Publishers \& Akadémiai Kiadó, Amsterdam, Budapest, 11-230.

Popov, G. V. 1994. The fauna of hoverflies (Diptera, Syrphidae) of the Donetsk region. The Kharkov Entomological Society Gazette, 2 (2), 42-82 [In Russian].

Prokhorov, A. V. 2019. New records of the hoverflies (Diptera: Syrphidae) from Russia. Ukrainska Entomofaunistyka, 10 (2), 1-6.

Prokhorov, A. V., Popov, G. V. 2017. The first records of Eristalis picea (Diptera: Syrphidae) from Ukraine and comparison with E. obscura. Ukrainska Entomofaunistyka, 8 (2), 11-15.

Prokhorov, A. V., Popov, G. V., Shparyk, V. Yu. 2020. New records of the hover flies (Diptera, Syrphidae) from Ukraine. IV. Zoodiversity, 54 (1), 17-30. DOI 10.15407/zoo2020.01.017

Prokhorov, A. V., Popov, G. V., Zaika, M. I. 2017. The first records of Melangyna lucifera (Diptera: Syrphidae) from Ukraine. Ukrainska Entomofaunistyka, 8 (1), 16. 
Prokhorov, A. V., Popov, G. V., Zaika, M. I. 2018 a. New records of hoverflies (Diptera, Syrphidae) from Ukraine. I. Milesiini and Rhingiini. Vestnik Zoologii, 52 (1), 13-20.

Prokhorov, A. V., Popov, G. V., Zaika, M. I. 2018 b. New records of hoverflies (Diptera, Syrphidae) from Ukraine. II. Brachyopini and Merodontini. Vestnik Zoologii, 52 (2), 125-136.

Prokhorov, A. V., Popov, G. V., Zaika, M. I. 2018 c. New records of hoverflies (Diptera, Syrphidae) from Ukraine. III. Pipizinae and Syrphinae. Vestnik Zoologii, 52 (3), 241-250.

Reemer, M., Renema, W., Van Steenis, W., Zeegers, T., Barendregt, A., Smit, J. T., Van Veen, M. P., Van Steenis, J., Van der Leij, L. J. J. M. 2009. De Nederlandse Zweefvliegen (Diptera: Syrphidae). Nederlandse Fauna 8. Nationaal Natuurhistorisch Museum Naturalis, knnv Uitgeverij, European Invertebrate Survey, Nederland, Leiden, 1-442.

Ricarte, A., Marcos-García, M. Á. 2017. A checklist of the Syrphidae (Diptera) of Spain, Andorra and Gibraltar. Zootaxa, 4216 (5), 401-440.

Rotheray, G. E. 1994. Color Guide to Hoverfly Larvae (Diptera, Syrphidae) in Britain and Europe. Derek Whiteley, Sheffield, 1-156. [= Dipterists Digest (1993), 9].

Saribiyik, S. 2014. Checklist of Turkish Flower Flies (Diptera: Syrphidae). Munis Entomology \& Zoology,9 (1), $570-585$.

Speight, M. C. D. 1987. External morphology of adult Syrphidae (Diptera). Tijdschrift voor Entomologie, 130, $141-175$.

Speight, M. C. D. 2020. Species accounts of European Syrphidae, 2020. Syrph the Net, the database of European Syrphidae (Diptera), 104, 1-314. Syrph the Net publications, Dublin.

Speight, M.C.D., Claussen, C. 1987. Redefinition of Cheilosia ahenea and C. argentifrons with records extending the known range of these species in Western Europe (Diptera, Syrphidae). Annales de la Société Entomologique de France (Nouvelle série), 23 (3), 299-308.

Speight, M. C. D., Sarthou, J.-P. 2017. StN keys for the identification of the European species of various genera of Syrphidae 2017. Syrph the Net, the database of European Syrphidae (Diptera), 99, 1-139. Syrph the Net publications, Dublin.

Speight, M. C. D., Sommaggio, D. 2010. On the presence in Switzerland of Microdon myrmicae Schönrogge et al., 2002, Xanthogramma dives (Rondani, 1857) and X. stackelbergi Violovitsh, 1975 (Diptera: Syrphidae). Entomo Helvetica, 3, 139-145.

Speight, M. C. D., Sarthou, J.-P., Vanappelghem, C., Sarthou, V. 2018. Maps of the departmental distribution of syrphid species in France (Diptera: Syrphidae). Syrph the Net, the database of European Syrphidae (Diptera), 100, 1-80. Syrph the Net publications, Dublin.

Ssymank, A. 2012. Contributions to the fauna of hoverflies (Diptera: Syrphidae) of north-eastern Greece, with special focus on the Rhodope Mountains with the Natura 2000 site Periochi Elatia, Pyramis Koutra. Studia dipterologica, $19(1 / 2), 17-57$.

Ståhls, G., Stuke, J.-H., Vujić, A., Doczkal, D., Muona, J. 2004. Phylogenetic relationships of the genus Cheilosia and the tribe Rhingiini (Diptera, Syrphidae) based on morphological and molecular characters. Cladistics, 20, 105-122.

Stănescu, C., Pârvu, C. 2005. Syrphids (Diptera: Syrphidae) of Romania. Cheklist, phenology, distribution. Travaux du Muséum National d'Histoire Naturelle «Grigore Antipa», 48, 177-202.

Stubbs, A. E., Falk, S. J. 2002. British hoverflies: an illustrated identification guide, 2nd edition. British Entomological and Natural History Society, Henry Ling Ltd., The Dorset Press, Dorchester, 1-469.

Thompson, F. C., Rotheray, G. 1998. Family Syrphidae. In: Papp, L., Darvas, B., eds. Contributions to a Manual of Palearctic Diptera (with special reference to flies of economic importance), 3 (Higher Brachycera), Science Herald, Budapest, 81-139.

Tóth, S. 2011. Magyarország zengőlégy faunája (Diptera: Syrphidae) [Hoverfly fauna of Hungary (Diptera: Syrphidae)]. e-Acta Naturalia Pannonica, Supplementum 1, 1-408.

Tóth, S. 2014. Additional data to the Hoverfly fauna of South West Bulgaria (Diptera: Syrphidae). Natura Somogyiensis, 24, 197-220.

Van Eck, A. 2011. A Checklist of the hoverflies of Portugal. Boletín de la Sociedad Entomológica Aragonesa, 49, 127-144.

Van Steenis, J. 2011. Swedish hoverfly records (Diptera: Syrphidae). Entomologisk Tidskrift, 132 (3), 187-193.

Van Steenis, W., de Groot, M., Van Steenis, J. 2013. New data on the hoverflies (Diptera: Syrphidae) of Slovenia. Acta entomologica Slovenica, 21 (2), 131-162.

Van Steenis, J., Van Steenis, W., Ssymank, A., Van Zuijen, M.P., Nedeljković, Z., Vujić, A., Radenković, S. 2015. New data on the hoverflies (Diptera: Syrphidae) of Serbia and Montenegro. Acta entomologica Serbica, 20, 67-98.

Van Steenis, J., Nedeljković, Z., Tot, T., van der Ent, L.-J., van Eck, A., Mazánek, L., Šebić, A., Radenković, S, Vujić, A. 2019. New records of hoverflies (Diptera: Syrphidae) and the rediscovery of Primocerioides regale Violovitsh for the fauna of Serbia. Biologia Serbica, 41 (1), 94-103.

Van Veen, M. P., 2010. Hoverflies of Northwest Europe. Identification keys to the Syrphidae. Second edition. KNNV Publishing, Utrecht, 1-248.

Verlinden, L. 1991. Zweefvliegen (Syrphidae). In: Van Goethem, J. (Hoofdredacteur), Fauna van België. Vol. 39. Koninklijk Belgisch Instituut voor Natuurwetenschappen, Bruxelles (Brussel), 1-298 [In Dutch] 
Verlinden, L. 2020. Records of Syrphidae (Diptera) from various regions of the Alps, the Vosges and the French Jura, 1982-1999. Syrph the Net, the database of European Syrphidae (Diptera), 108, 1-49. Syrph the Net publications, Dublin.

Vujić, A. 1996. Genus Cheilosia Meigen and related genera (Diptera: Syrphidae) on the Balkan peninsula. Monographs. Department of Natural Sciences, Matica srpska, Novi Sad, 1-194.

Vujić, A., Šimić, S., Radenković, S. 2001. Endangered species of hoverflies (Diptera, Syrphidae) on the Balkan peninsula. Acta entomologica Serbica, 5 (1/2), 93-105.

Vujić, A., Ståhls, G., Radenković, S. 2018. Hidden European diversity: a new monotypic hoverfly genus (Diptera: Syrphidae: Eristalinae: Rhingiini). Zoological Journal of the Linnean Society, 20, 1-24.

Vujić, A., Radenković, S., Trifunov, S., Nikolić, T. 2013. Key for European species of the Cheilosia proxima group (Diptera, Syrphidae) with a description of a new species. ZooKeys, 269, 33-50. doi: 10.3897/ zookeys.269.4619

Wakkie, B. 2020. The world of Syrphidae website. Available from: http://www.syrphidae.com/checklist_ overview.php (Accessed: April 27, 2020).

Williams, M. E. de C., Toussidou, M., Speight, M. C. D. 2011. Hoverflies (Diptera, Syrphidae) new to Greece from the Rhodope Mountains of Thrace and eastern Macedonia, including Simosyrphus scutellaris new to Europe. Dipterists Digest, 18, 181-198.

Wolff, D. 1998. On the hoverfly fauna of the Berlin region (Diptera, Syrphidae). Volucella, 3 (1/2), 87-131.

Received 21 April 2020

Accepted 24 April 2020 